\title{
Identifying the phyllosilicate minerals of hypogene ore deposits in lateritic saprolites using the near-IR spectroscopy second derivative methodology
}

\author{
Maximilien Mathian ${ }^{\mathrm{a}, \mathrm{b}, *}$, Benoit Hebert ${ }^{\mathrm{a}}$, Fabien Baron $^{\mathrm{c}}$, Sabine Petit ${ }^{\mathrm{a}}$, Jean-Luc Lescuyer ${ }^{\mathrm{d}}$, \\ Renan Furic $^{\mathrm{d}}$, Daniel Beaufort ${ }^{\mathrm{a}}$

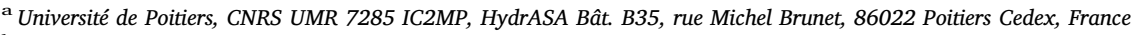 \\ ${ }^{\mathrm{b}}$ Sorbonne Universités, UPMC Univ Paris 06, CNRS UMR 7590 IMPMC, 4 Place Jussieu, 75005 Paris, France \\ ${ }^{\mathrm{c}}$ Université de Nantes - CNRS UMR 6112 Laboratoire de Planétologie et Géodynamique (LPG), 2 rue de la Houssinière, 44322 Nantes, France \\ d LA MANCHA Services France, 4-14, rue d'Aguesseau, 75008 Paris, France
}

Keywords:

Field-based near-infrared spectroscopy

Laterite

Alteration halo

Clay minerals

Mining geology

\begin{abstract}
A B S T R A C T
Infrared field-based reflectance spectroscopy in the Visible - Near-Infrared - Short-wave Infrared (VIS-NIR-SWIR) domain is a useful tool in mining geology particularly efficient for investigating the clay mineralogy of alteration haloes around ore deposits. It is used as a routine technique for the basic identification, mapping and semiquantification of clay mineral species. However, the use of this technique for prospecting in hypogene deposits at depth in intertropical areas is strongly limited because of the presence of a thick, kaolinite-rich lateritic cover. Due to the strong IR absorption of kaolinite and the overlapping of its IR bands with those of most of the phyllosilicates in the SWIR domain, the use of field based near-infrared spectroscopy does not permit efficient identification and mapping of the phyllosilicates inherited from hypogene alteration that persist in the saprolite of lateritic profiles.

In this paper, we propose a methodology to enhance the detection and semi-quantification of hypogene phyllosilicate minerals in kaolinite-rich lateritic saprolites using calibration curves. Those curves are built from the NIR spectra of binary admixtures of kaolinite or smectite with muscovite, Fe-Mg chlorite, clinochlore or talc in different known proportions.

For each admixture series, calibration curves were established, based on investigation of two regions of interest within the NIR domain (1350-1470 nm and 2080-2500 nm) using a field-based spectrometer. For each binary mixture series of phyllosilicates, the second derivative of the NIR spectra was used to enhance the detection of the diagnostic absorption bands of each type of phyllosilicate, and hence to optimize the calculation of the intensity ratios between the diagnostic bands of the phyllosilicate components as a function of their percentage in the mixture. In presence of large amounts of lateritic kaolinite, the detection limit of the major types of hypogene phyllosilicates has been found at ranges from 5 to $10 \mathrm{wt} \%$ of the total clay content using the second derivative of the NIR spectra acquired with a field-based spectrometer. Above these aforementioned limits of detection, the semi-quantitative data obtained by comparing the NIR reflectance spectra of natural samples with those of the calibration curves could permit to map hypogene alteration haloes directly from the lateritic saprolite.
\end{abstract}

Finally the described approach has been successfully tested on natural samples from the skarn deposits of the Ity gold mine (Ivory Coast).

\section{Introduction}

Field-based near-infrared (NIR) reflectance spectroscopy has been routinely used in mining geology for over 30 years. It is now a robust and low-cost method that allows automatic analysis of IR-sensitive minerals in the Visible Near-Infrared - Short-wave Infrared (VIS-NIR-SWIR) length range of the electromagnetic spectrum $\left(350-2500 \mathrm{~nm} / 4000-28,600 \mathrm{~cm}^{-1}\right)$ at field scale.
This spectroscopic technique aids in mineral identification and enables to perform a semi-quantitative determination of the major IRsensitive minerals that make up ore deposits and their associated alteration halos. The IR radiation reflected from the surface of a sample is characteristic of the IR-sensitive minerals (e.g., phyllosilicates, carbonates, phosphates, and sulfates) (Dill, 2016) that have wavelength positions and distinctive profiles that can be used for their identification.

\footnotetext{
* Corresponding author at: Université de Poitiers, CNRS UMR 7285 IC2MP, HydrASA Bât. B35, rue Michel Brunet, 86022 Poitiers Cedex, France.

E-mail address: maximilien.mathian@gmail.com (M. Mathian).
} 
Several articles have considered the use of VIS-NIR-SWIR spectroscopy for ore characterization (Ramanaidou and Wells, 2015; Dill, 2016), to map ore deposits through airborne or space-based hyperspectral methods (Thompson et al., 1999; Lisowiec et al., 2007) and for the identification of gangue minerals and alteration haloes during mining exploration (Hunt and Ashley, 1979; Pontual et al., 1997; Herrmann et al., 2001; Hauff, 2014). Because critical anion complexes, such as the hydroxyls (OH groups) in the lattices of phyllosilicates, are stimulated by selected vibrations in the VIS-NIR-SWIR range, this methodology is particularly efficient for investigating the alteration mineralogy zoning, which is quite diagnostic of the proximity to ore in hydrothermal deposits (Edwards and Atkinsons et al., 1986; Herrmann et al., 2001; Sun et al., 2001; Post and Crawford, 2014; Hauff, 2014; Dalm et al., 2017).

VIS-NIR-SWIR spectroscopy has been efficiently used to map mineral associations within alteration systems related to low- and highsulfidation gold deposits, porphyries, kimberlites, skarns, IOCG (iron oxide copper gold) deposits and unconformity uranium deposits (Hauff, 2014). Unfortunately, the use of field-based NIR reflectance spectroscopy to obtain a detailed understanding of hypogene deposits and their alteration systems is still limited to core logging of deposits exposed in deep drill holes in countries with mid-latitude climatic conditions. The presence of a thick lateritic overburden precludes the identification of the residual hypogene phyllosilicates that can be identified in outcrops. Due to the abundance of supergene kaolinite (and smectite in a lesser degree) in lateritic profiles and the very high IR sensitivity of such clay minerals (Joussein et al., 2001), the identification of the contributions from the residual hypogene phyllosilicates using the VIS-NIR-SWIR spectra acquired from routine analysis is very difficult.

Moreover, in the case of mixtures of clay minerals in natural samples, the diagnostic NIR absorption bands commonly overlap. The positions of the diagnostic bands of kaolinite in the SWIR domain are very close to those of most phyllosilicates commonly observed in alteration halos surrounding hypogene deposits (e.g., micas, illite, chlorite, and talc, as well as others).

The aim of this study is to enhance the detection and identification of hypogene phyllosilicates in natural samples of lateritic saprolites based on detailed analysis of NIR spectra of controlled series of binary mixtures of kaolinite or smectite with muscovite, chlorite or talc within two specific wavelength ranges (1350-1470 and 2080-2500 nm, respectively). For each type of binary mixture series of phyllosilicates, the second derivative of NIR spectra was used to carefully determine the position of the diagnostic absorption bands of each type of phyllosilicate and hence to optimize the calculation of the intensity ratios between the diagnostic bands of the phyllosilicate components as a function of their percentage in the mixture. Semi-quantitative information could also be obtained from the resulting calibration curves.

A comparison of the detection limit obtained for talc, muscovite and different types of chlorite mixed with kaolinite or montmorillonite is presented as a function of the approach applied (routine vs. second derivative method), the type of spectrometer (laboratory-based vs. field-based spectrometers) and the investigated region of interest of the IR spectrum (1350 to 1470 vs 2080 to $2500 \mathrm{~nm}$ ). The method has been successfully applied to natural samples of the lateritic saprolite that overlies the skarn gold deposit of Ity (Ivory Coast).

\section{Sampling}

\subsection{Binary mixtures of phyllosilicates}

The limits of detection for minerals vary between mineral mixtures. It is necessary to first build calibration files of percentage mixtures (Hauff, 2014). Binary mixtures of phyllosilicates were prepared and mixed with quartz (which is inactive in the IR regions of interest investigated) to simulate a wide range of natural saprolites. To carry out this task, strictly controlled amounts of clay minerals were mixed with the orthoquartzitic sand of Fontainebleau $\left(\mathrm{SiO}_{2}>98 \%\right)$, which was first washed free of clay minerals using multiple washing and ultrasonic treatments.

Different types of clay references were considered. 1) Georgia kaolinite KGa-1 (Source Clay Repository of the Clay Minerals Society) and 2) Wyoming montmorillonite Swy-2 (Source Clay Repository of the Clay Minerals Society) were used as analogues to supergene phyllosilicates. 3) Muscovite (Brazil), 4) Mg chlorite (Luzenac, France), 5) FeMg chlorite (Cauterets, France) and 6) talc (Luzenac, France) were used as analogues to hypogene phyllosilicates. In the following parts of this study, the Mg-chlorite will be referred as clinochlore, and the Fe-Mg chlorite will be referred to "chlorite".

This study focused on 5 series of binary mixtures composed of $400 \mathrm{mg}$ of sand and $100 \mathrm{mg}$ of reference clays. Each series included 15 samples corresponding to different ratios of hypogene phyllosilicates and supergene phyllosilicates (0/100, 2/98, 5/95, 10/90, 20/80, 30/ $70,40 / 60,50 / 50$ and the reverse). Kaolinite-muscovite, kaolinite-talc, kaolinite-chlorite, smectite-chlorite and smectite-clinochlore mixtures were investigated in this study.

\subsection{The natural samples of the Ity gold mine (Ivory Coast)}

The Ity gold mine district is located in the southern portion of the Ivory Coast, approximately $500 \mathrm{~km}$ northwest of Abidjan and $100 \mathrm{~km}$ from the Sassandra fault (Béziat et al., 2016). The local geology has been determined by deep drilling performed by the SMI Company under the saprolite horizon. The gold deposit is located in a small remnant of the Birimian formation (Milesi et al., 1989; Leube et al., 1990; Feybesse and Milési, 1994; Hirdes et al., 1996; Lawrence et al., 2013a,b) that has been intruded by granodiorite and rhyolites (Fig. 1). During their emplacement, these intrusions developed skarn aureoles (Einaudi, 1982; Meinert et al., 2005), which are the primary causes of gold mineralisation (Béziat et al., 2016).

The entire mine area is constantly leached during the rainy season (up to 9 months) and deep laterite formations have replaced the basement rocks at depths of up to $130 \mathrm{~m}$, including 50 to $120 \mathrm{~m}$ of saprolite (Béziat et al., 2016). Below the massive laterite cover, specific depthrelated mineralogical variations have been identified in the saprolite as a function of the nature of the hypogene hydrothermal alteration observed at greater depths, in the unweathered skarn deposit (Mathian et al., 2015). Four main types of skarn-related mineral assemblages were identified, each of which is characterized by at least one specific type of hypogene phyllosilicate. 1) Muscovite occurs in intrusions and related volcano-sedimentary formations; 2) Fe-Mg chlorite occurs in the endoskarn; 3) clinochlore occurs at the endoskarn/exoskarn transition; and 4) talc occurs in the exoskarn.

In a previous study focused on the laterite saprolite (Mathian et al., 2015), twenty-two samples were investigated (Appendices 5 and 6). Those samples, called Ity 1 to Ity 21 , were divided in three families: 1 ) the hypogene phyllosilicates dominant, with a clear XRD and IR signal of those minerals; 2) the supergene phyllosilicates dominant, without any XRD or IR signal of hypogene phyllosilicates; 3) the samples with a small amount of hypogene phyllosilicates, with low intensity peaks in XRD patterns and a very weak IR signal of those minerals (i.e. no specific diagnostic bands are visible). Eight samples of this last family have been chosen to test the limit of the second derivative methodology on natural samples. These samples were located in the saprolite and at the base of the lateritic profile that overlies the skarn deposit. They are all representative of a specific zone within the skarn system (specifically, the intrusive pluton, endoskarn, endoskarn/exoskarn transition, exoskarn, and unaltered host rocks). They were selected to be the proxy of samples coming from the saprolite basement (Ity 1, 9, 14 and 19) and from a higher part of the saprolite (Ity 4, 7, 12 and 20).

All samples were crushed and sieved to size of $<50 \mu \mathrm{m}$ to avoid any preferential mineral orientation. They were also dried using a microwave oven at $850 \mathrm{~W}$ for $3 \mathrm{~min}$ to remove the water absorbed onto the sample material without any structural disturbance. 


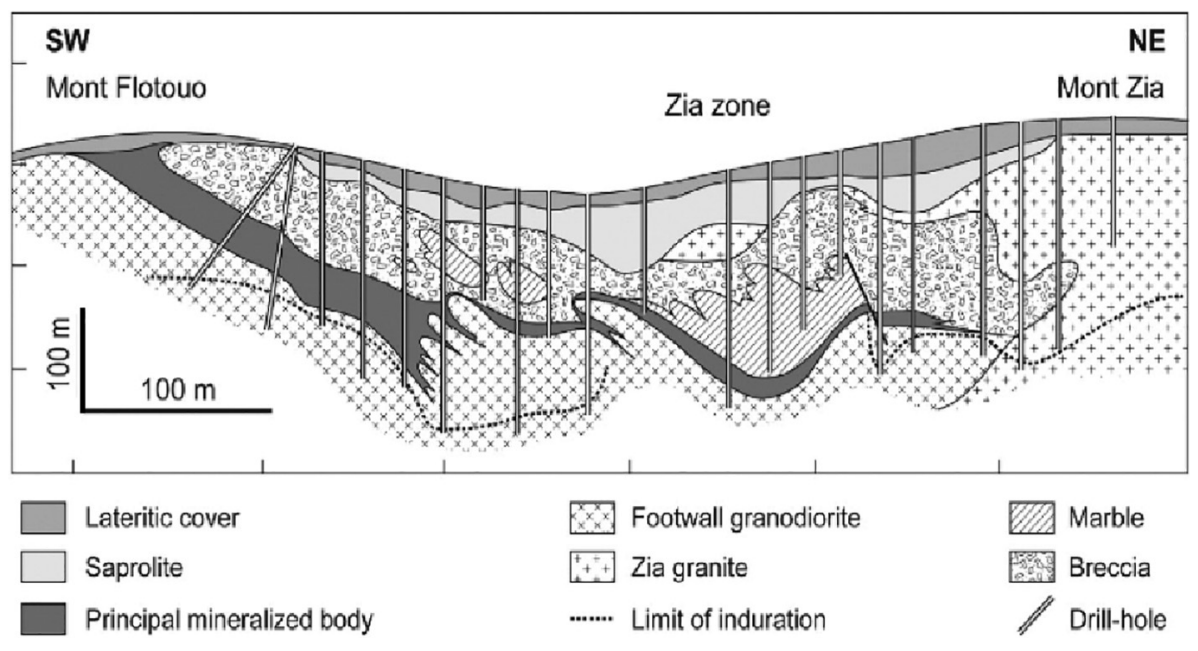

Fig. 1. Geological cross-section of the Ity gold mine deposits. (For interpretation of the references to colour in this figure legend, the reader is referred to the web version of this article.)

(Modified from Béziat et al., 2016.)

\section{Methodology}

Laboratory NIR spectra of natural and artificial binary samples were acquired directly from powders using a Thermo Scientific Integrating Sphere NIR with an internal InGaAs detector set on a Thermo Scientific Nicolet 6700 spectrometer equipped with a white light source and a $\mathrm{CaF}_{2}$ beam splitter. Spectra were obtained by averaging 100 spectra with a resolution of $4 \mathrm{~cm}^{-1}$ in the 1000-2500 $\mathrm{nm}$ range.

Field VIS-NIR-SWIR spectra were acquired using an ASD TerraSpec $4{ }^{\circledR}$ Standard-Res field-based spectrometer in the $350-2500 \mathrm{~nm}$ range. The spectral resolution was $3 \mathrm{~nm}$ in the $350-1000 \mathrm{~nm}$ range and $10 \mathrm{~nm}$ in the $1000-2500 \mathrm{~nm}$ range. Final spectra were obtained by averaging 50 spectra.

The second derivative procedure was employed to enhance the resolution of sharply defined features (which are hereafter named "components") where these overlap with broad bands. The components intensities were measured from the second derivative spectra from a baseline at $\mathrm{Y}=0$. The second derivative NIR spectra were obtained from the laboratory spectrometer using $\mathrm{OMNIC}^{\mathrm{TM}}$ software with a set of 13 points within the range of interest (number of points within the interval) and a polynomial function of order 3 . For the field-based VISNIR-SWIR spectrometer, second derivative spectra were calculated automatically using The Spectral Geologist ${ }^{\mathrm{TM}}$ (TSG) software without modifiable parameters. Note that those parameters of calculation are not presented in the software or in the notice.

\section{Results}

\subsection{NIR diagnostic bands of reference clay minerals}

All phyllosilicate subtypes can be identified using diagnostics bands from two main domains of the NIR spectrum (Fig. 2) (Petit et al., 2004a; Madejova et al., 2011; Bishop et al., 2008). The first NIR domain contains wavelengths ranging from 2080 to $2500 \mathrm{~nm}$ (wavenumbers from 4800 to $4000 \mathrm{~cm}^{-1}$ ). It includes mainly combination bands generated by combinations of $\mathrm{OH}$ stretching and $\mathrm{OH}$ bending or lattice vibration modes (Baron and Petit, 2016). The second domain contains wavelengths ranging from 1350 to $1470 \mathrm{~nm}$ (wavenumbers from 7400 to $6800 \mathrm{~cm}^{-1}$ ). This spectral region contains mainly $2 \nu \mathrm{OH}$ bands, which represent the first harmonic of the $\mathrm{OH}$ stretching vibration subtype (Petit et al., 2004a). Hereafter, we present the characteristics of the diagnostic absorption bands of the different types of phyllosilicates investigated. The two domains will often be referred to as regions of interest (ROI).

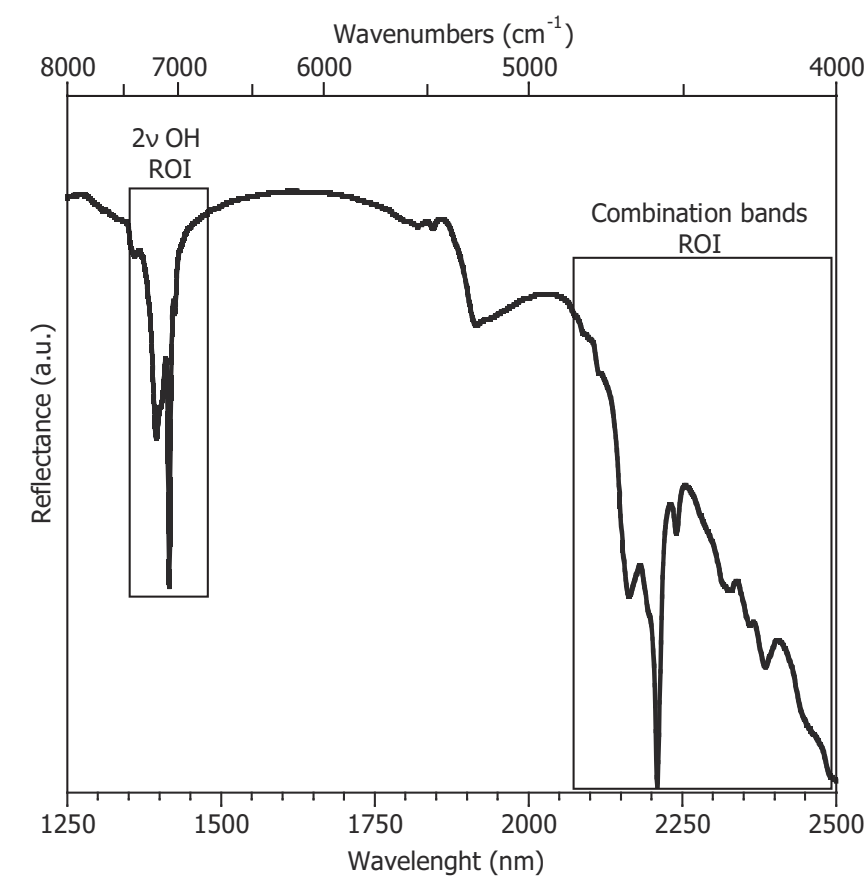

Fig. 2. The first region of interest (ROI) for phyllosilicates: $(\nu+\delta) \mathrm{OH}$, from 2080 to $2500 \mathrm{~nm}$, and the second ROI with $2 \mathrm{NOH}$ from 1350 to $1470 \mathrm{~nm}$.

\subsection{Kaolinite}

Kaolinite is a 1:1 phyllosilicate and is the main supergene phyllosilicate resulting from lateritic alteration under tropical weathering conditions. The NIR spectrum of this mineral has 3 diagnostics bands in both of the regions of interest (Figs. 3a and $4 a$ ). In the $2 \nu \mathrm{OH}$ ROI, kaolinite is characterized by an intense band at $1415 \mathrm{~nm}\left(7065 \mathrm{~cm}^{-1}\right)$ and two other bands at 1406 and $1395 \mathrm{~nm}\left(7111\right.$ and $\left.7169 \mathrm{~cm}^{-1}\right)$ that are attributed to $2 \mathrm{\nu Al}_{2} \mathrm{OH}$ vibration modes (Petit et al., 1999, 2004a). In the combination ROI of the NIR spectra, the three main diagnostic $\mathrm{OH}$ combination bands (Fig. 3a), which are located at 2210, 2194 and $2165 \mathrm{~nm}$ (4524, 4558 and $4627 \mathrm{~cm}^{-1}$, respectively), yield very similar signals and are attributed to $(\nu+\delta) \mathrm{Al}_{2} \mathrm{OH}$ vibration modes (Petit et al., 1999, 2004a).

\subsection{Muscovite}

White micas and illite are very common minerals in porphyry, skarn, epithermal and granite-related ore deposits worldwide (Cerny 


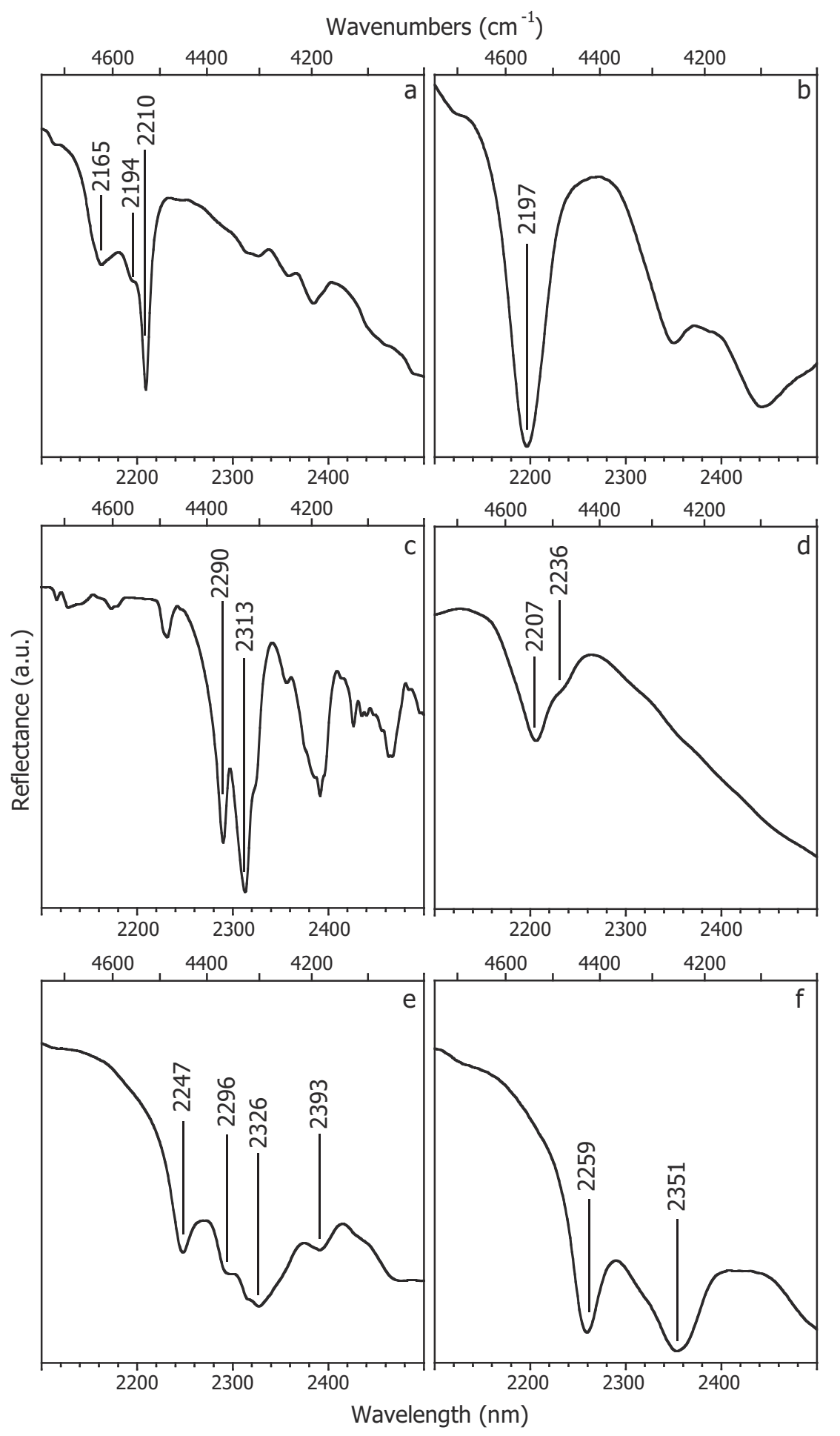

Fig. 3. Diagnostic bands of considered phyllosilicates in the first ROI (4800 to $4000 \mathrm{~cm}^{-1}$ ). a: kaolinite, b: muscovite, c: talc, d: montmorillonite, e: clinochlore, f: Fe-Mg chlorite.

et al., 2005; Meinert et al., 2005; Seedorff et al., 2005; Simmons et al., 2005); Cerny et al., 2005). Muscovite and illite present very similar infrared spectra (Vaculikova and Plevova, 2005), which are characterized by two main intense diagnostic bands (Figs. 3b and 4b) that are located at $1412 \mathrm{~nm}\left(7083 \mathrm{~cm}^{-1}\right)$ and $2197 \mathrm{~nm}\left(4552 \mathrm{~cm}^{-1}\right)$. These bands are attributed to $2 \nu \mathrm{Al}_{2} \mathrm{OH}$ and $(\nu+\delta) \mathrm{Al}_{2} \mathrm{OH}$ respectively (Post and Noble, 1993; Madejova et al., 2011).

\subsection{Talc}

spectrum of talc is characterized by four intense bands (Figs. 3c and 4c). In the second ROI, the band located at $1391 \mathrm{~nm}\left(7186 \mathrm{~cm}^{-1}\right)$ is very sharp and is attributed to $2 \mathrm{vMg}_{3} \mathrm{OH}$ vibrations. The second band appears at $1398 \mathrm{~nm}\left(7152 \mathrm{~cm}^{-1}\right)$ and is attributed to $2 \mathrm{LMg}_{2} \mathrm{Fe}^{2+} \mathrm{OH}$ vibrations (Petit et al., 2004a,b). In the combination ROI (Fig. 3c), the two bands related to talc are located at 2290 and $2313 \mathrm{~nm}$ (4366 and $4324 \mathrm{~cm}^{-1}$ ). The precise explanation of their positions, which are due to stretching and bending combination bands, is not fully understood (Petit et al., 2004b; Madejova et al., 2011).

Talc is a 2:1 non-swelling phyllosilicate rich in $\mathrm{Mg}$. The NIR 


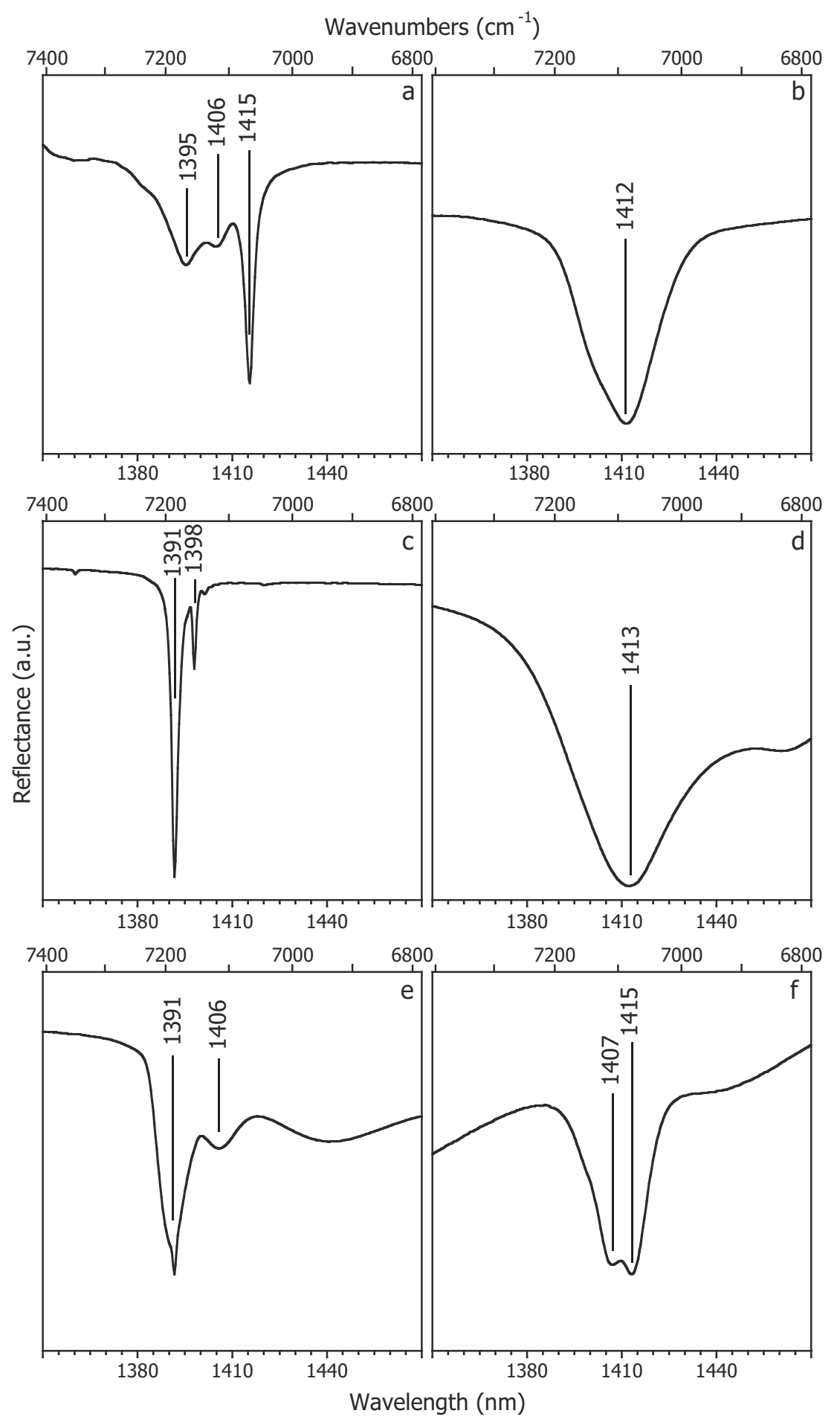

Fig. 4. Diagnostic bands of considered phyllosilicates in the second ROI (7400 to $6800 \mathrm{~cm}^{-1}$ ). a: kaolinite, b: muscovite, c: talc, d: montmorillonite, e: clinochlore, f: Fe-Mg chlorite.

\subsection{Montmorillonite}

Montmorillonite is a 2:1 swelling clay mineral that is common near the bottom of lateritic profiles. In the combination region, two bands located at 2207 and $2236 \mathrm{~nm}$ (4529 and $4472 \mathrm{~cm}^{-1}$ ) could be used as diagnostic bands to assess the presence of this smectite-type mineral (Fig. 3d). They are due to $(\nu+\delta) \mathrm{Al}_{2} \mathrm{OH}$ and $(\nu+\delta) \mathrm{AlFe}^{3+} \mathrm{OH}$ vibrations, respectively (Post and Noble, 1993; Petit et al., 2004a; Bishop et al., 2008; Madejova et al., 2011). It can also be easily recognized as a broad, complex band in the $2 \mathrm{\nu OH}$ region (Madejova et al., 2011) at $1413 \mathrm{~nm}\left(7077 \mathrm{~cm}^{-1}\right)$ that corresponds to $2 \mathrm{\nu Al}_{2}-\mathrm{OH}$ vibrations and to the first overtone of water molecules involved in weak hydrogen bonding (Fig. 4d).

\subsection{Chlorites}

Clinochlore (Figs. 3e and 4e) and Fe-Mg chlorite (Figs. 3f and 4f) have distinctive diagnostic bands. The 1407 and $1415 \mathrm{~nm}$ (7106 and $7067 \mathrm{~cm}^{-1}$ ) bands are characteristic of Fe-Mg chlorite in the second ROI. The Fe-Mg chlorite combination bands in the first ROI are well defined at 2259 and $2351 \mathrm{~nm}$ (4426 and $4253 \mathrm{~cm}^{-1}$ ). The later chlorite bands have not been explained by a precise $\mathrm{OH}$ vibration signals 

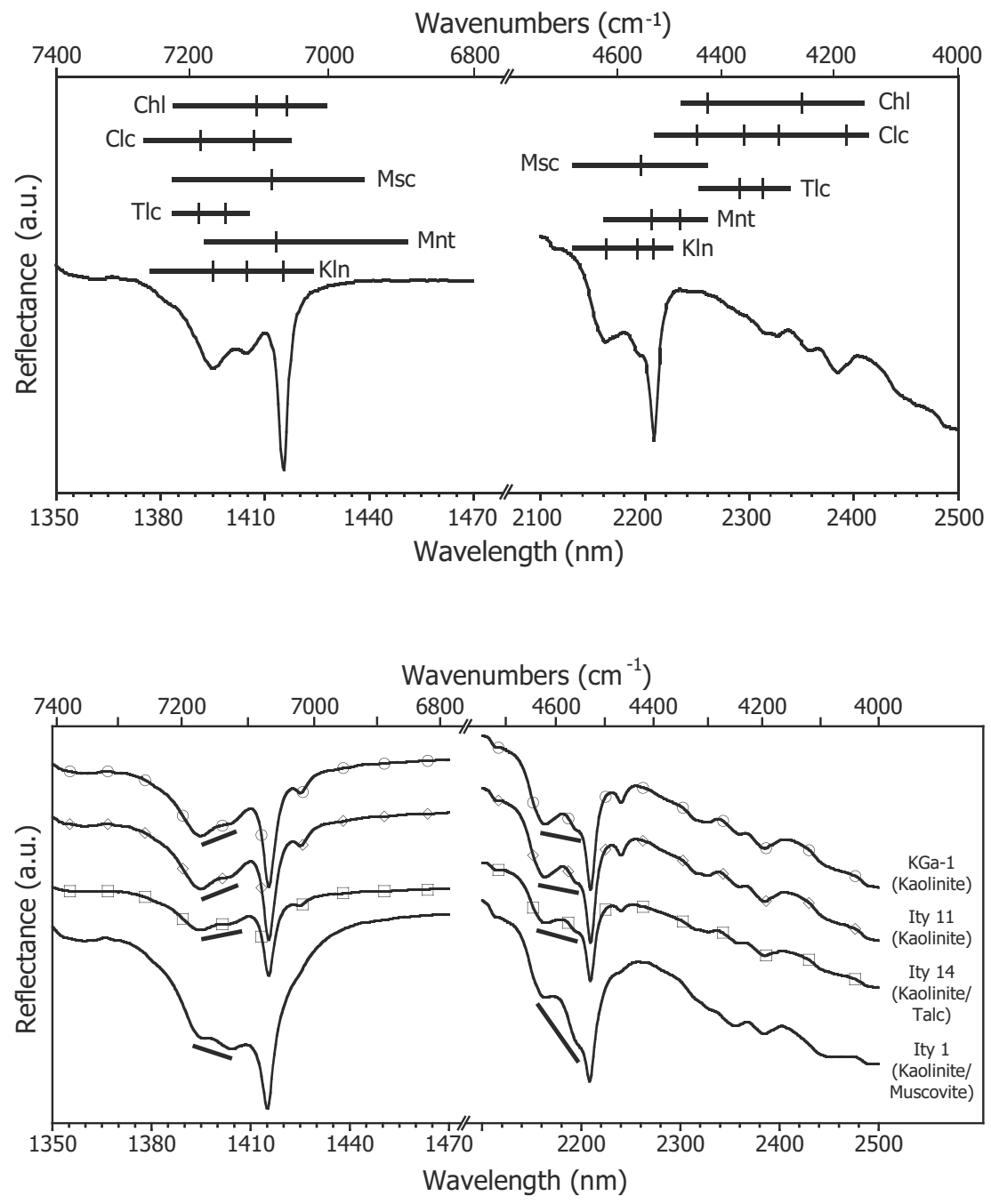

Fig. 5. Position and overlapping possibilities of the considered clay mineral diagnostic bands in the first and second ROI. Kaolinite and muscovite are overlapping in both regions as well as clinochlore and chlorite with montmorillonite. Talc only overlaps with kaolinite in the second ROI.
Fig. 6. IR spectra of kaolinite reference (KGa-2) and 3 natural samples rich in phyllosilicates: Ity 1 (kaolinite and muscovite), Ity 11 (kaolinite) and Ity 14 (kaolinite talc) in both ROI. Only kaolinite bands are visible, but the intensity of Ity 1 and 14 bands are different from those of the KGa-2 reference and Ity 11. Slope changes are visible on the kaolinite spectra under the influence of overlapped hidden bands of talc or muscovite.
(Madejova et al., 2011). In the second ROI, clinochlore has a broad band at $1391 \mathrm{~nm}\left(7185 \mathrm{~cm}^{-1}\right)$ that corresponds to $2 \mathrm{LMg}_{3} \mathrm{OH}$ vibrations, similar to the one observed in talc spectra (Ferrage et al., 2003). Clinochlore shows another band at $1406 \mathrm{~nm}\left(7111 \mathrm{~cm}^{-1}\right)$ that is not described in literature. In the first ROI, the diagnostic bands for clinochlore overlap. Four main combination bands could be identified for this mineral at 2247, 2296, 2326 and $2393 \mathrm{~nm}$ (4450, 4356, 4299, and $\left.4179 \mathrm{~cm}^{-1}\right)$.

\subsection{Identification of index absorption bands from NIR spectra of phyllosilicate mixtures}

Supergene clay minerals (kaolinite and smectite) often constitute $>50 \%$ of the modal compositions of saprolites. They strongly absorb in the NIR domain, making the identification of the contribution of small percentages of hypogene phyllosilicates very difficult. However, even if the NIR bands of these phyllosilicates have very similar positions and hence overlap strongly, the difference in their intensity of IR absorbance at each wavelength results in additional shoulders in the IR spectrum when compared to the spectra of a reference kaolinite (KGa1) and a reference smectite (Swy2). Consequently, the occurrence of shoulders and changes in the IR bands profiles observed in the NIR spectra (Fig. 5) can be attributed to the contributions from the other phyllosilicate minerals present in the mixture. The presence of small amounts of talc and muscovite induced a change in the profiles of IR bands indicative of kaolinite (Fig. 6) with 1) a band apparition $\left(1391 / 2290 \mathrm{~cm}^{-1}\right)$ and/or 2) an inversion of the slope of kaolinite bands. This phenomenon was observed in both ROIs (1350-1470 nm and $2080-2500 \mathrm{~nm}$ ) and is due to the increasing influence of the hidden bands of talc and muscovite. The presence of minor amount of chlorite in smectite-rich samples induced slight changes in both the shape and width of the main smectite band (Fig. 7). Such changes in the NIR profiles are, however, very weak.

All of the binary mixtures have been analyzed using both field-based and laboratory infrared spectrometers. Some variations were observed in NIR spectrum profiles as a function of the increasing percentages of hypogene phyllosilicates in the mixture. It was then possible to determine the detection limits of these minerals in kaolinite-rich and smectite-rich mixtures (Appendices 1, 2, 3 and 4).

For each series of binary mixtures, a visual limit of detection has been determined as the minimal percentage at which the hypogene phyllosilicate can be identified in the NIR spectrum from the occurrence of new bands or the evident modification of band profiles, without any spectral processing.

For kaolinite-rich admixtures, muscovite, talc and chlorite were detected visually in the NIR spectra when their percentages exceeded $40 \%, 10 \%$ and $40 \%$, respectively. For smectite-rich admixtures, Fe-Mg chlorite and clinochlore were detected when their percentages exceeded $50 \%$ and $20 \%$. Table 2 presents all the established visual limits of detection for both spectrometers and both regions of interest for each binary mixture series. 


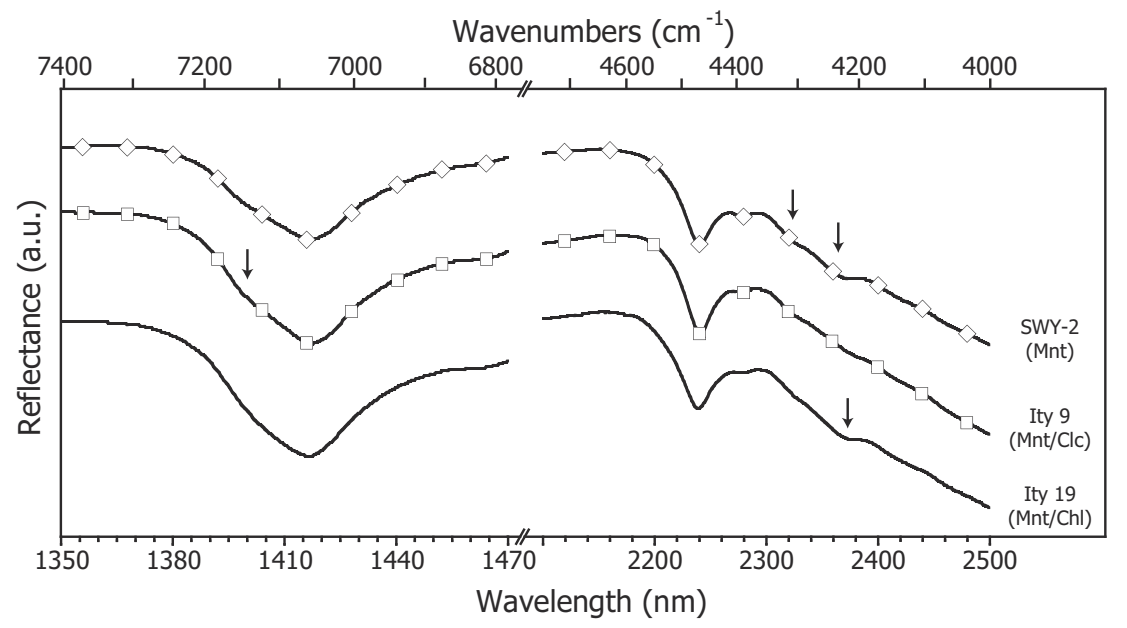

Fig. 7. IR spectra of montmorillonite reference (Swy-2) and 2 natural samples rich in phyllosilicates: Ity 9 (clinochlore and montmorillonite), Ity 19 (clinochlore and montmorillonite) in both ROI. Only smectite bands are visible, but IR spectra slope changes are visible in both natural samples traducing the presence of both chlorite types.

\subsection{Improving the identification of hypogene phyllosilicates by using the second derivative curve of the spectra}

The presence of minor amounts of phyllosilicates phases in natural samples cannot be easily detected because it consists only in subtle differences (i.e. inflection points) in the NIR reflectance spectra. However slight changes in the profile of the reflectance spectra can be highlighted by use of an algorithm that permit to calculate the second derivative curve. The second derivative curves of NIR spectra are especially useful for separating peaks of overlapping bands and are a good noise filter since changes in base line have negligible effect on derivatives. Every maximum (or minimum) observed in second derivative curve corresponds to an inflection point of the original reflectance spectrum and the components oriented upwards in the second derivative curves correspond to inflection points at a particular wavelength position of absorption bands. The fact that the intensity of the second derivative components is proportional to the intensity and width of their related IR bands in the reflectance spectrum (Fig. 8) makes it suitable for a semi-quantitative approach.

The derivation processes of the reflectance IR spectra were made using the software and parameters described in the corresponding methodology section. This procedure improved the detection limit of hypogene phyllosilicates. Fig. 8a and b show reflectance spectra for a kaolinite (50\%) - muscovite (50\%) binary admixture obtained from both field-based and laboratory spectrometers within the two regions of interest. The resolution of the NIR profiles obtained using the fieldbased spectrometer is lower than that of the NIR profiles from the laboratory spectrometer, particularly in the region between 1350 and $1470 \mathrm{~nm}$ (7400 to $\left.6800 \mathrm{~cm}^{-1}\right)$. Fig. $8 \mathrm{c}$ and d show the second derivative curve calculated from the previous reflectance spectra.

The use of the second derivative overcomes the lower resolution of the field-based NIR spectrometer and makes it as reliable as the

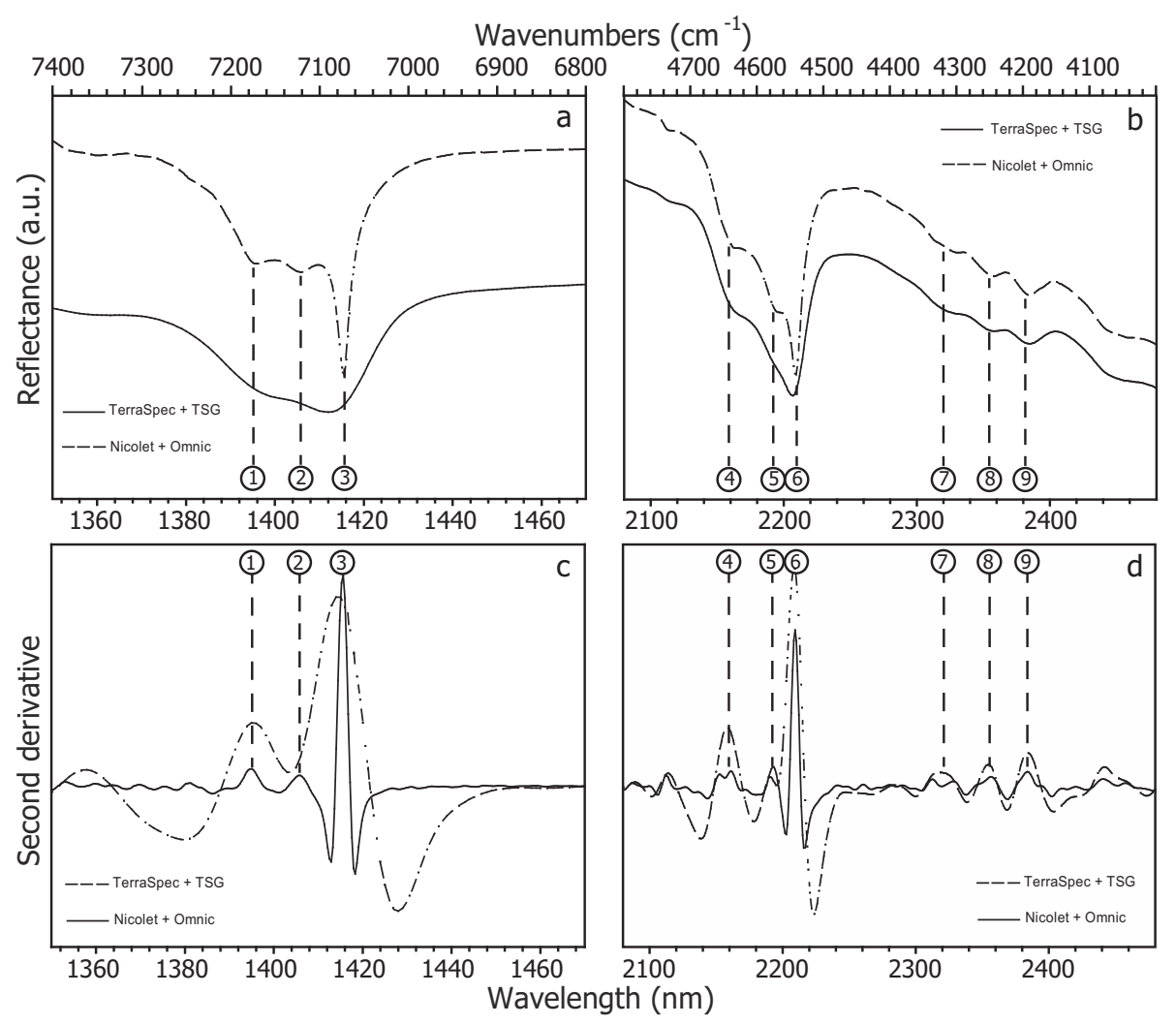

Fig. 8. Reflectance (a and b) and second derivative (c and d) spectra for a 50-50 kaolinite-muscovite binary admixture in both regions of interest using the laboratory and the field spectrometer. 

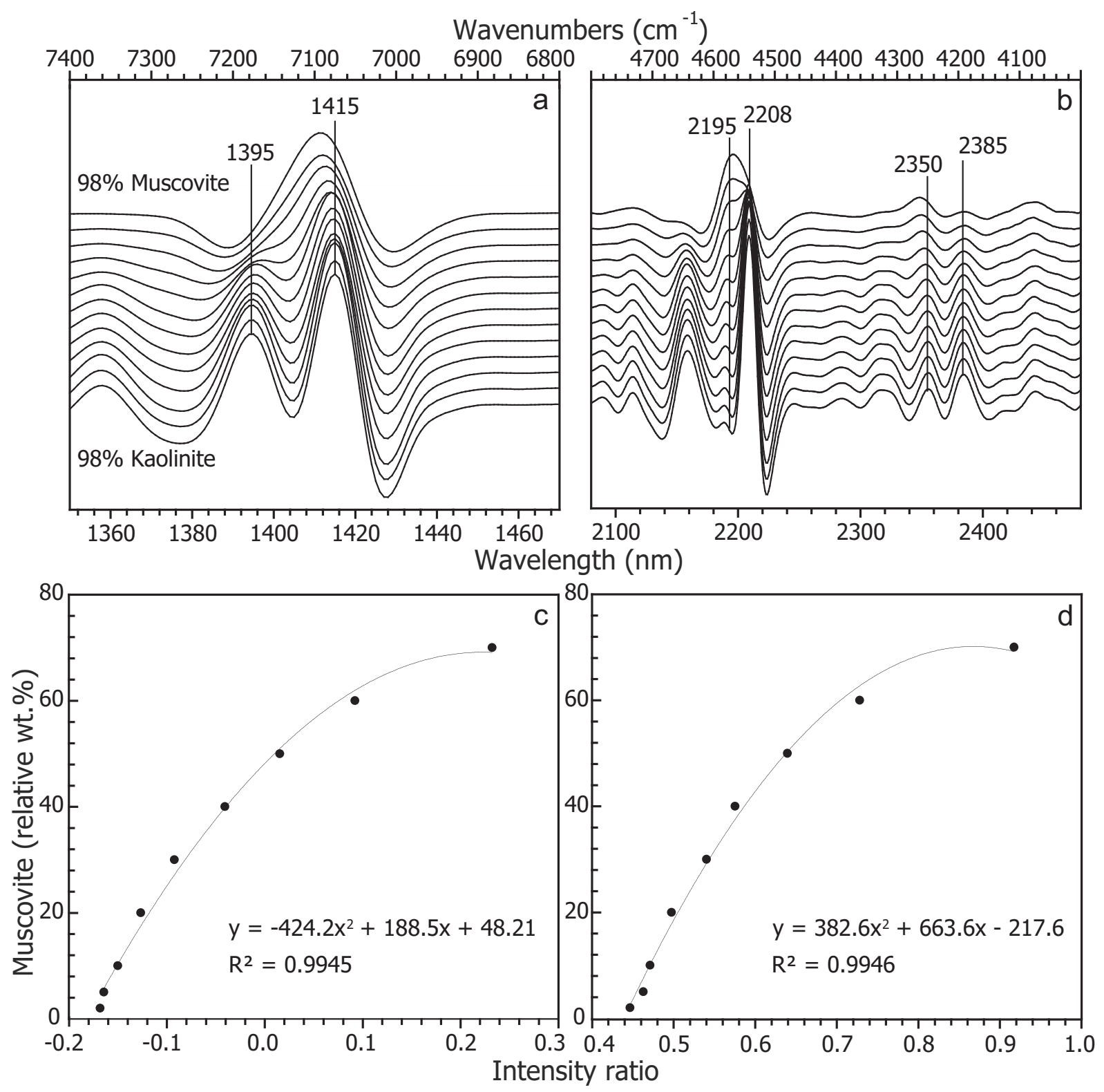

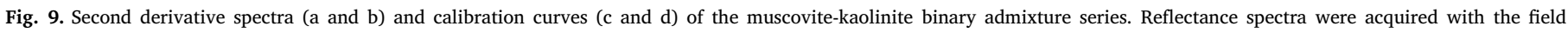
spectrometer and derived using TSG.

laboratory spectrometer for the identification of band. The use of second derivative spectra allowed accurate measurement of intensity ratios between components whose positions fit with those of the index NIR bands of the phyllosilicates of interest. The aim of this work was to be able to provide a method that could be applied directly on the field, we will consider hereafter only the spectra obtained from the fieldbased spectrometer.

This section focuses on the detection limit of each type of hypogene phyllosilicate disseminated in a kaolinite or smectite matrix using the second derivative profiles of the binary admixtures. In the following figures, the spectra were offset for clarity, and an error of $\pm 5 \mathrm{~nm}$ and $\pm 10 \mathrm{~cm}^{-1}$ has been assumed for the IR band positions.

\subsection{Kaolinite-muscovite mixtures}

The second ROI (Fig. 9a) was not found useful for identification of low relative amounts of muscovite; as it allowed the identification of this mineral only when its percentage exceeds $70 \mathrm{wt} \%$ of the phyllosilicate content in the mixture.

In the first ROI (Fig. 9b), the presence of muscovite was indicated by two components at 2195 and $2350 \mathrm{~nm}$. Here, kaolinite showed four main components at 2165, 2208, 2360 and $2385 \mathrm{~nm}$. The qualitative parameter for the detection of muscovite in a kaolinite-rich sample was calculated following the ratio of intensities (called " $\mathrm{I}_{\text {component position 1/ }}$ component position 2" and measured as explained in the methodology section) between the muscovite component at $2195 \mathrm{~nm}$ and the kaolinite component at $2208 \mathrm{~nm}$ given by $\mathrm{I}_{2195} / \mathrm{I}_{2208}$. The calibration curve, i.e. the correlation between the intensity ratio and the amount of the considered phyllosilicate compared to the total mass of phyllosilicates in the admixture, was obtained from a least square polynomial regression (Fig. 9c). Only one fitting method was used in this study but improvements could be obtained after testing other methods on these datasets. It is important to remind that these calibration curves are mathematical proxies to describe the second derivative components 


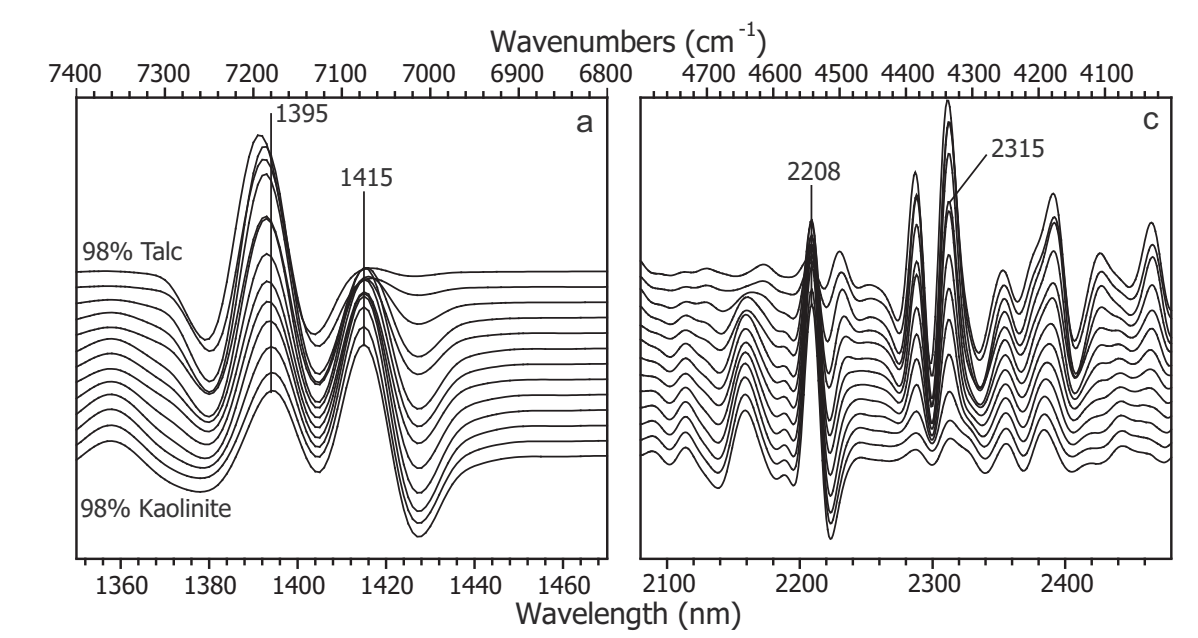

Fig. 10. Second derivative spectra (a and c) and calibration curves (b and d) of the talc-kaolinite binary admixture series. Reflectance spectra were acquired with the field spectrometer and derived using TSG.

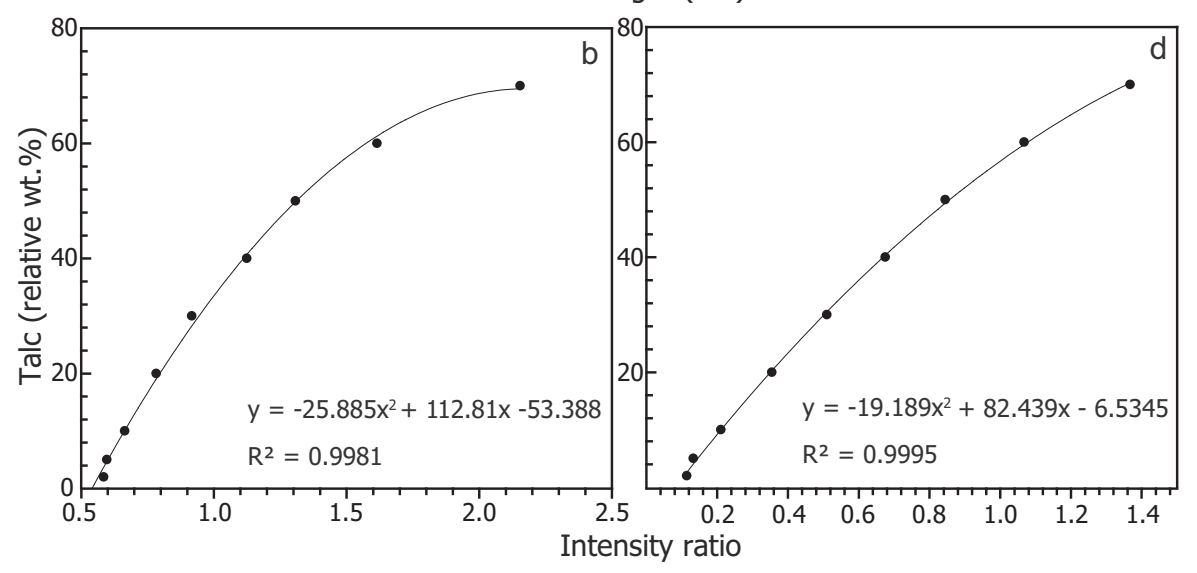

evolution due to phyllosilicate content variation.

The intensity ratio can be negative because we also chose to consider the negative intensity values of the muscovite component that occur at $2195 \mathrm{~nm}$. The correlation between the qualitative parameter and the muscovite content is validated for muscovite percentages ranging between 2 and $70 \mathrm{wt} \%$. This correlation permits the detection of muscovite once its percentage reaches $5 \mathrm{wt} \%$ in the clay mixture.

The $2360 \mathrm{~nm}$ component shifted to $2350 \mathrm{~nm}$ while moving from the kaolinite-rich to the muscovite-rich mixtures. The intensity of the $2350 \mathrm{~nm}$ component remained constant, while the intensity of the component at $2385 \mathrm{~nm}$ decreased. A second qualitative parameter was defined as $\mathrm{I}_{2350} / \mathrm{I}_{2385}$. A correlation (Fig. 9d) was observed for mixtures containing percentages of muscovite ranging from 2 to $70 \mathrm{wt} \%$. This second qualitative parameter allows the detection of muscovite once its percentage reaches $10 \mathrm{wt} \%$.

\subsection{Kaolinite-talc mixtures}

In the second ROI (Fig. 10a) the component at $1395 \mathrm{~nm}$ is due to both kaolinite and talc. A slight shift towards $1388 \mathrm{~nm}$ is observed when the relative amount of kaolinite increases. The qualitative parameter used for talc is $\mathrm{I}_{1395} / \mathrm{I}_{1415}$ (Fig. 10b).

In the first ROI (Fig. 10c), kaolinite and talc showed several components. The $2315 \mathrm{~nm}$ and $2208 \mathrm{~nm}$ components were selected as representative of the contribution of talc and kaolinite, respectively. The qualitative parameter used for talc is the intensity ratio of both components, i.e., $I_{2315} / I_{2208}$ (Fig. $10 \mathrm{~d}$ ). For both regions of interest
(1350-1470 nm and 2080-2480 nm), the limit of detection limit of talc mixed with kaolinite is $5 \mathrm{wt} \%$.

\subsection{Kaolinite-Fe-Mg chlorite mixtures}

Within the second ROI (Fig. 11a) chlorite showed only a broad peak at approximately $1410 \mathrm{~nm}$, which was partly overlapped by two peaks related to kaolinite (1395 and $1415 \mathrm{~nm}$ ). The qualitative parameter was given by $\mathrm{I}_{1415} / \mathrm{I}_{1395}$. A good correlation between the relative content of chlorite, and the qualitative parameter has been observed for samples containing from 2 to $50 \mathrm{wt} \%$ chlorite (Fig. 11b). The detection limit of chlorite mixed with kaolinite is $5 \mathrm{wt} \%$.

In the first ROI (Fig. 11c), chlorite is characterized by three components located at 2205, 2255 and $2350 \mathrm{~nm}$. Kaolinite showed two main components at 2160 and $2208 \mathrm{~nm}$, and a triplet was observed at 2320, 2355 and $2385 \mathrm{~nm}$. Both chlorite and kaolinite have components near $2350 \mathrm{~nm}$. However, a shift from 2355 to $2350 \mathrm{~nm}$ is observed with increasing chlorite content in the binary mixtures. The qualitative parameter used for chlorite is $\mathrm{I}_{2250} / \mathrm{I}_{2355}$. A good correlation has been observed between the proportion of chlorite, expressed as a percentage, in the mixture and its qualitative parameter (Fig. 11d). The detection limit of chlorite mixed with kaolinite is also $5 \mathrm{wt} \%$.

\subsection{Smectite-Fe-Mg chlorite mixtures}

In the first ROI, the main components of smectite and chlorite are located at $2205 \mathrm{~nm}$ and $2255 \mathrm{~nm}$ respectively (Fig. 12a). The 


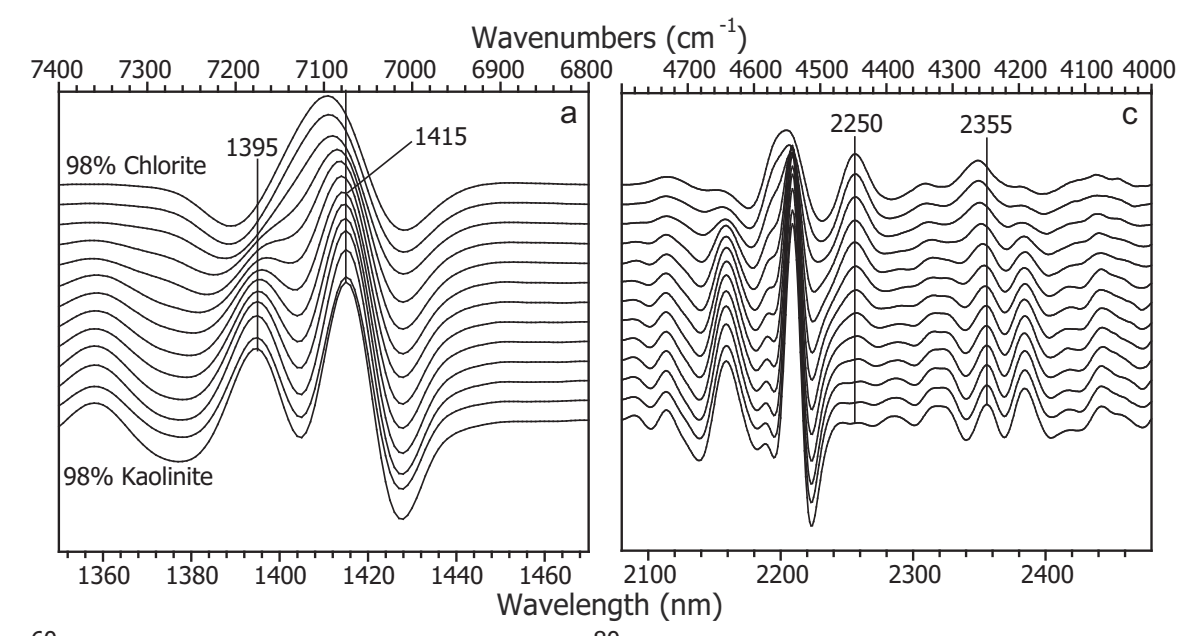

Fig. 11. Second derivative spectra (a and c) and calibration curves (b and d) of the chlorite-kaolinite binary admixture series. Reflectance spectra were acquired with the field spectrometer and derived using TSG.

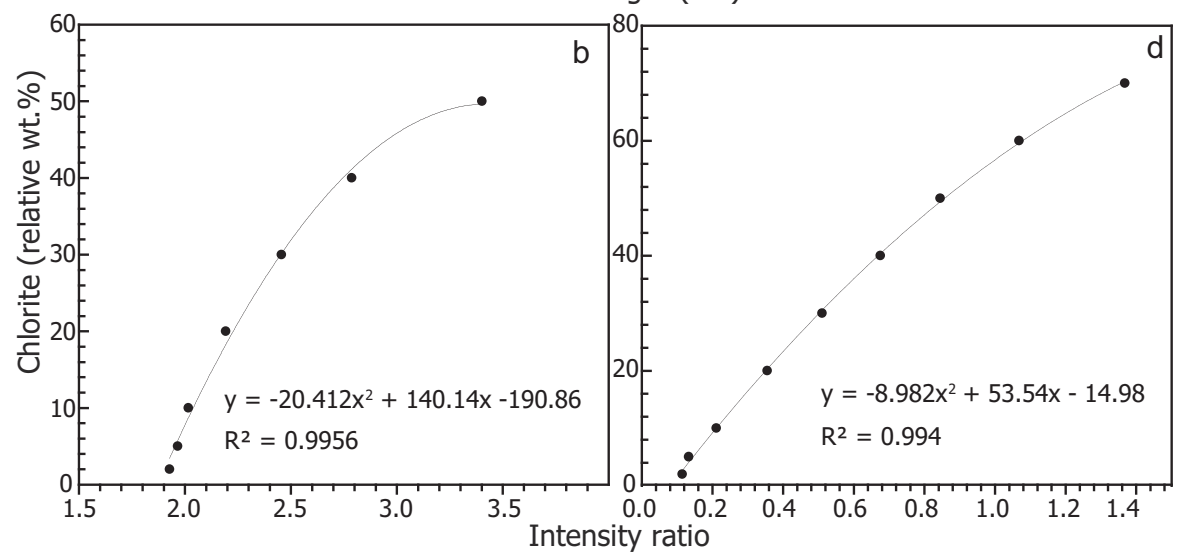

qualitative parameter used for chlorite mixed with smectite is $\mathrm{I}_{2255}$ / $\mathrm{I}_{2205}$. A good correlation is observed (Fig. 12b) between this qualitative parameter and the relative content of chlorite. The detection limit of chlorite mixed with smectite is $5 \mathrm{wt} \%$. No significant changes in the profile of the secondary derivative spectrum are observed in the second ROI.

\subsection{Smectite-clinochlore mixtures}

Unlike the smectite-chlorite binary admixtures (Fig. 12a), a gradual change can be observed between two distinct components of the clinochlore/smectite series in the second ROI (Fig. 13a). These two

Wavenumbers $\left(\mathrm{cm}^{-1}\right)$
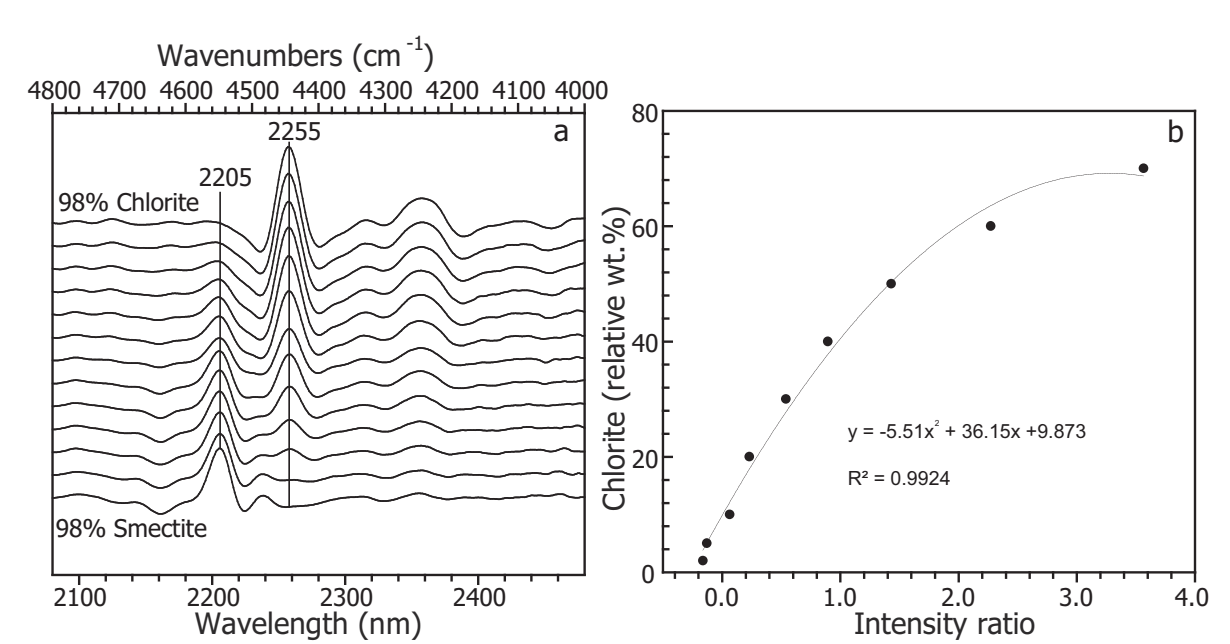

components occurring at 1392 and $1415 \mathrm{~nm}$ correspond to clinochlore bands, however smectite also share this $1415 \mathrm{~nm}$ band. The qualitative parameter for clinochlore is $\mathrm{I}_{1392} / \mathrm{I}_{1415}$, and there is a good correlation with the percentage of clinochlore in the mixture (Fig. 13b).

In the first ROI (Fig. 13c), the two components at 2208 and $2238 \mathrm{~nm}$ were related to smectite. Clinochlore has two main components located at 2245 and $2290 \mathrm{~nm}$ and several broader components from 2300 to $2400 \mathrm{~nm}$. The qualitative parameter for clinochlore is given by $\mathrm{I}_{2245} /$ $\mathrm{I}_{2208}$. Fig. 13d showed a good correlation between the percentage of clinochlore and the intensity ratio $\mathrm{I}_{2245} / \mathrm{I}_{2208}$. The detection limit of clinochlore is equals to $10 \mathrm{wt} \%$ in both regions of interest.

Fig. 12. Second derivative spectra (a) and calibration curve (b) of the chlorite-smectite binary admixture series. Reflectance spectra were acquired with the field spectrometer and derived using TSG. 


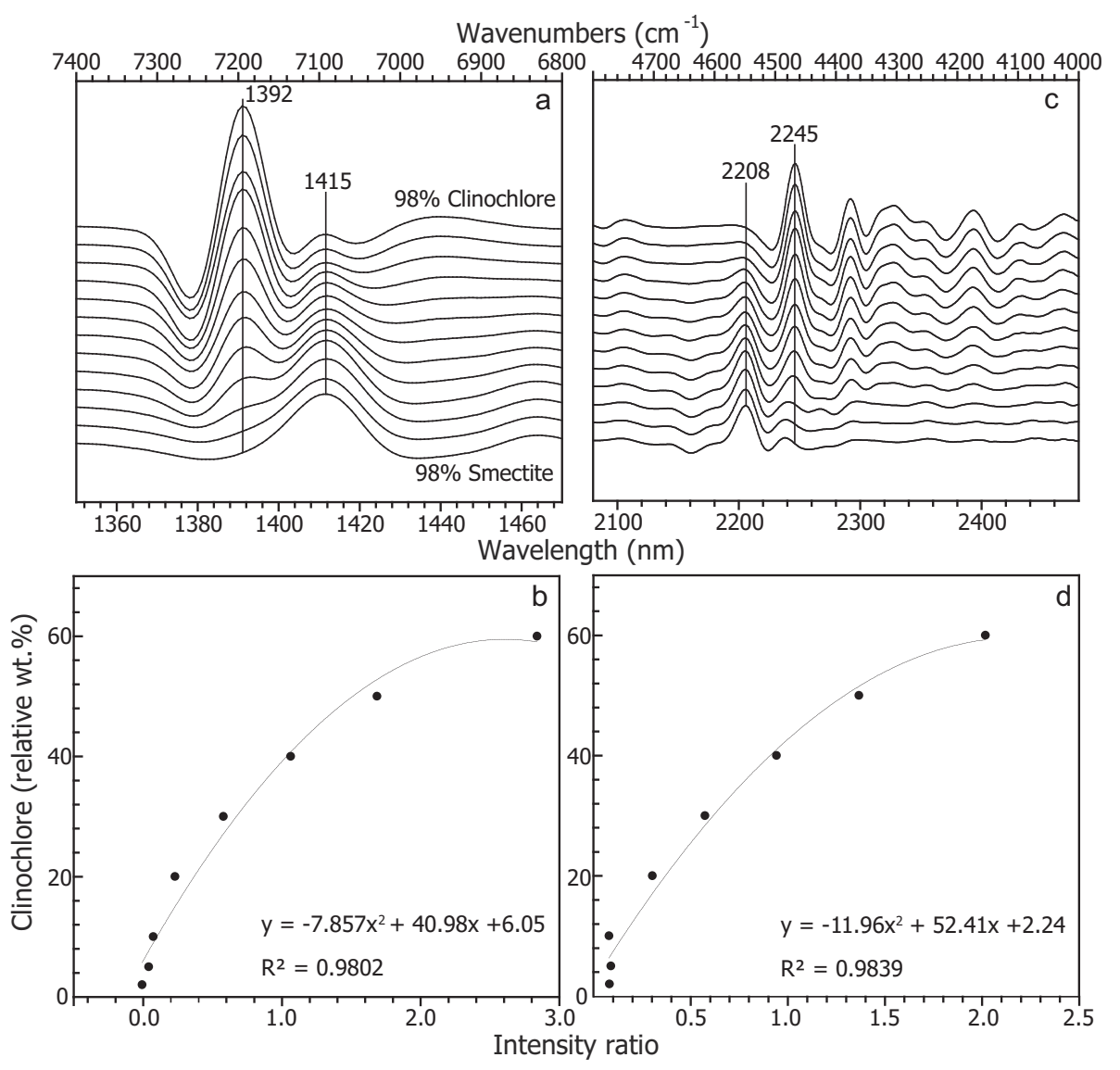

Fig. 13. Second derivative spectra (a and c) and calibration curves ( $b$ and d) of the clinochlore-smectite binary admixture series. Reflectance spectra were acquired with the field spectrometer and derived using TSG.

\section{Application to natural samples}

The complete procedure about how to use the second derivative methodology is described step by step in Appendix 7. The 8 samples selected for the application of this second derivative methodology showed weak (Ity 1, 9, 14 and 19) to very weak contributions (Ity 4, 7, 12 and 20) of hypogene phyllosilicates in the NIR spectra (Fig. 14). However, their presence was confirmed by XRD analysis of the finegrained fraction of each sample. Four different phyllosilicate associations, previously described in the methodological sections of this paper, were observed: kaolinite - muscovite (Ity 1 and 12), smectite - Fe-Mg chlorite (Ity 19 and 20), smectite - clinochlore (Ity 9 and 4), and kaolinite - talc (Ity 14 and 7).

The resolution of the NIR spectra collected from these natural samples is lower than those collected for the binary mixtures. This is due to the difference in matrix composition that exists between experimental and natural samples, and more particularly to the presence of significant amount of inactive minerals (i.e. which do not absorb the IR radiation in the NIR domain) in the samples of saprolite (quartz, some silicates...).

For each mixture of clay minerals, qualitative parameters (Appendix 8) were calculated for both ROI using the methodology described in this paper. These qualitative parameters were compared to the values established as detection limits from calibration curves (Figs. 8 to 12). In samples where the qualitative parameter values from the NIR spectra were above the detection limit, an estimation of the relative proportions of phyllosilicates was performed using the corresponding calibration curves equations within each ROI (cf. the results section).
For Ity 19 and 20, containing Fe-Mg chlorite and Ity 9 and 4, containing clinochlore in a smectite-rich matrix, the use of the second ROI was not found relevant. Such samples seem to have very low relative content of chlorite. However, chlorite and clinochlore were much more easily detected using the first ROI qualitative parameters.

The use of the calibration curves formula of those parameters for both types of samples show that Ity 19 and 20 contain a chlorite relative content around $11 \mathrm{wt} \%$ and $13 \mathrm{wt} \%$ of the total phyllosilicate content. On the other hand, Ity 9 and 4, appeared to have a relative clinochlore content of $10 \mathrm{wt} \%$ and $15 \mathrm{wt} \%$. Note that Ity 4 showed an intermediate NIR profile between those of the binary admixtures with relative clinochlore contents of 10 and $20 \mathrm{wt} \%$. Ity 14 and 7, which contained talc in a kaolinite-rich matrix, yielded qualitative parameters that correspond to values below the detection limit. It cannot be certified that talc is present in these samples. This methodology was then correctly applied to Ity 1 and 12, where muscovite was identified. The estimation of its relative content using calibration curve equations was successful, giving about 65 and $15 \mathrm{wt} \%$ respectively.

For each sample, estimations of the main phyllosilicates percentages have been done using a procedure based on XRD results and normative calculations (Quirt, 1995). Those estimations were made considering only the presence of the major phyllosilicates present within the sample and not the minor phases. The given percentages can so be considered as the maximum amount of hypogene and supergene phyllosilicates included in each samples.

The results of those calculations are presented in the Table 1 , it appears that the percentages of different types of hypogene phyllosilicates determined by NIR spectroscopy using the second derivative 
a

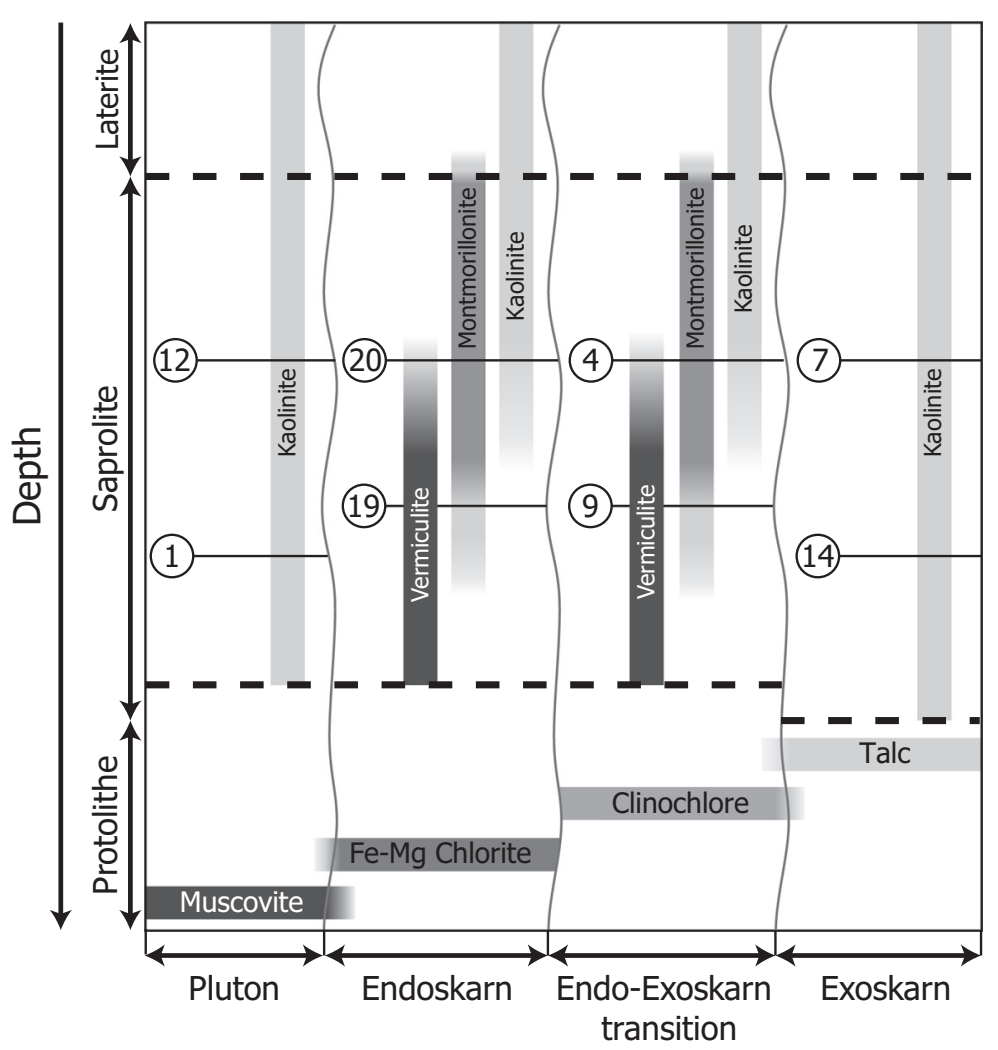

Fig. 14. Alteration zoning in the saprolite above the skarn deposit of Ity with specific phyllosilicate associations and location of the samples analyzed with NIR spectrometry using the second derivative method. Ity 1 and 12 are coming from unaltered pluton/volcano sediments and contain small amounts in muscovite. Ity 19 and 20 are coming from endoskarn and contain small amounts Fe-Mg chlorite. Ity 9 and 4 are coming from endo/exoskarn transition and contain small amounts of $\mathrm{Mg}$ chlorite (clinochlore). Ity 14 and 7 are coming from exoskarn and contain small amounts of talc. Note that no depth values are presented here because of the high variability of the laterite thickness (average of $10 \mathrm{~m}$ of depth) and of the saprolite (from 40 to $130 \mathrm{~m}$ )

b

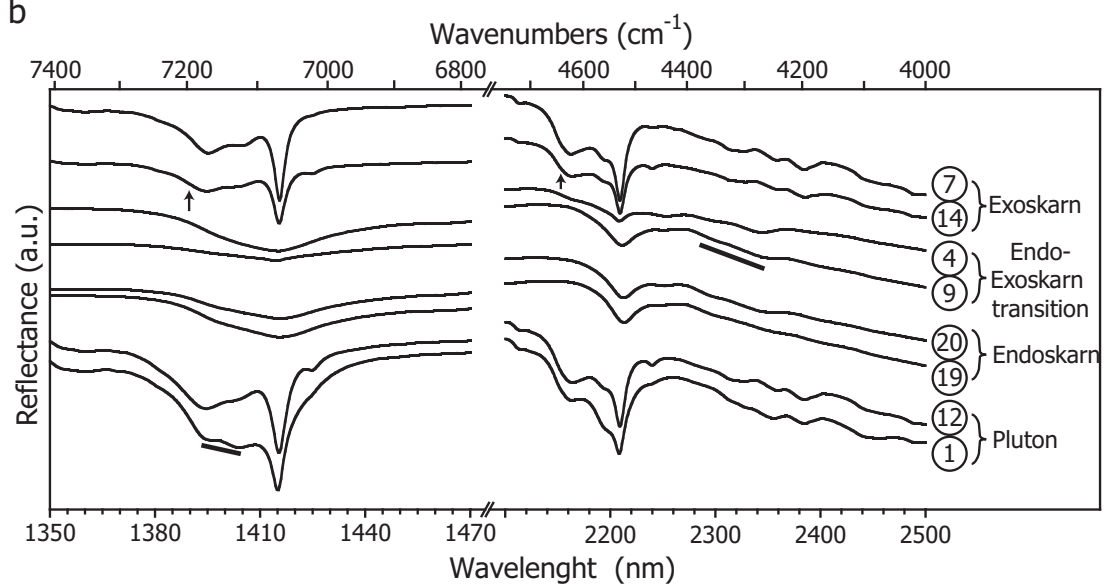

method are in agreement with the semi-quantitative estimations obtained from XRD and normative calculation. A variation up to $<15 \%$ is visible between both semi-quantitative estimations, probably due to the choice made during the normative calculations and the crystal-chemistry changes between the natural phyllosilicate and the one used to make the calibration curves. Indeed, substitutions and structural defects will have an influence on the IR bands and will so affect the second derivative components intensity.

The second derivative method was successfully applied to 8 samples from the Ity gold mine. It shown that it can be efficiently applied to natural samples to determine the nature of hypogene phyllosilicates disseminated in a lateritic saprolite, as well as providing semi-quantitative information about their relative abundance, which could be of interest for further mapping of the alteration at a regional scale.

\section{Concluding remarks}

Most of the major worldwide mining companies presently use fieldbased near-infrared spectroscopy for prospecting of ore deposits and acquiring in-depth knowledge of their associated alteration systems (Hauff, 2014). In addition to simple and instantaneous mineral identification, this methodology has great potential for the relative amounts of alteration minerals determination. It hence to map at field scales the alteration mineralogy zoning, which is often quite diagnostic of the proximity to ore. However, the utilization of field-based reflectance spectroscopy for qualitative and semi-qualitative investigations of phyllosilicates still requires improvement. In particular, care must be taken in the basic interpretation of the absorption features of the reflectance spectra if comparisons are only made with spectral data from 
Table 1

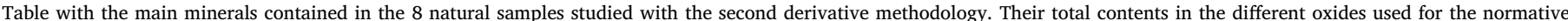

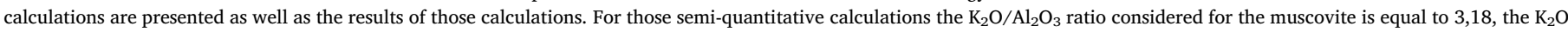

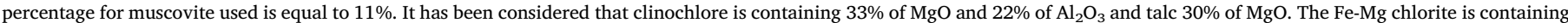

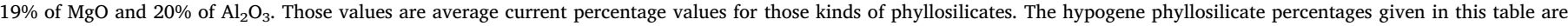

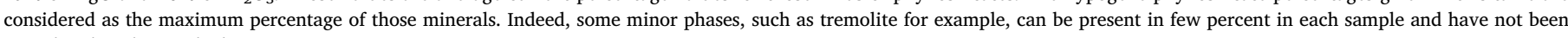
considered in those calculations.

\begin{tabular}{|c|c|c|c|c|c|c|c|c|c|c|}
\hline $\begin{array}{l}\text { Sample } \\
\text { name }\end{array}$ & $\begin{array}{l}\text { Main } \\
\text { phyllosilicates }\end{array}$ & $\mathrm{SiO}_{2}(\%)$ & $\mathrm{Al}_{2} \mathrm{O}_{3}(\%)$ & $\mathrm{Fe}_{2} \mathrm{O}_{3}(\%)$ & $\mathrm{MgO}(\%)$ & $\mathrm{K}_{2} \mathrm{O}(\%)$ & $\begin{array}{l}\% \text { hypogene } \\
\text { phyllosilicate }\end{array}$ & $\begin{array}{l}\% \text { supergene } \\
\text { phyllosilicate }\end{array}$ & $\begin{array}{l}\text { Ratio hypogene } \\
\text { phyllosilicate (\%) }\end{array}$ & $\begin{array}{l}\text { IR ratio hypogene } \\
\text { phyllosilicate (\%) }\end{array}$ \\
\hline Ity 1 & $\begin{array}{l}\text { Kaolinite, } \\
\text { muscovite }\end{array}$ & 76.03 & 14.39 & 0.88 & 0.22 & 2.68 & $24 \%$ & $15 \%$ & $61 \%$ & $65 \%$ \\
\hline Ity 12 & $\begin{array}{l}\text { Kaolinite, } \\
\text { muscovite }\end{array}$ & 60.05 & 21.45 & 6.07 & 0.14 & 0.33 & $3 \%$ & $54 \%$ & $5 \%$ & $15 \%$ \\
\hline Ity 19 & $\begin{array}{l}\text { Smectite, Fe-Mg } \\
\text { chlorite }\end{array}$ & 53.85 & 13.99 & 5.89 & 5.85 & 0.63 & $4 \%$ & $66 \%$ & $6 \%$ & $11 \%$ \\
\hline Ity 20 & $\begin{array}{l}\text { Smectite, Fe-Mg } \\
\text { chlorite }\end{array}$ & 46.6 & 15.39 & 8.42 & 8.68 & 1.46 & $21 \%$ & $56 \%$ & $27 \%$ & $13 \%$ \\
\hline Ity 9 & $\begin{array}{l}\text { Smectite, } \\
\text { clinochlore }\end{array}$ & 50.82 & 14.13 & 7.24 & 7.74 & 0.61 & $12 \%$ & $58 \%$ & $17 \%$ & $10 \%$ \\
\hline Ity 4 & $\begin{array}{l}\text { Smectite, } \\
\text { clinochlore }\end{array}$ & 48.38 & 15.66 & 8.1 & 2.9 & 0.48 & $9 \%$ & $69 \%$ & $11 \%$ & $15 \%$ \\
\hline Ity 14 & Kaolinite, talc & 38.1 & 28.68 & 16.44 & 0.07 & 0.04 & $0.002 \%$ & $75 \%$ & $<1 \%$ & Under limit \\
\hline Ity 7 & Kaolinite, talc & 36.46 & 31.67 & 14.36 & 0.2 & 0.05 & $0.006 \%$ & $83 \%$ & $<1 \%$ & Under limit \\
\hline
\end{tabular}

Table 2

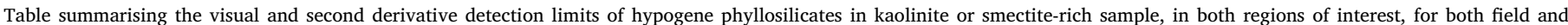
laboratory spectrometer. Percentages are weight percentages.

\begin{tabular}{|c|c|c|c|c|c|c|c|c|c|}
\hline \multirow[b]{2}{*}{$\begin{array}{l}\text { Supergene } \\
\text { phyllosilicate }\end{array}$} & \multirow[b]{2}{*}{$\begin{array}{l}\text { Hypogene } \\
\text { phyllosilicate }\end{array}$} & \multicolumn{4}{|c|}{ Laboratory NIR spectrometer } & \multicolumn{4}{|c|}{ Field NIR spectrometer } \\
\hline & & $\begin{array}{l}\text { Reflectance 1st } \\
\text { ROI }\end{array}$ & $\begin{array}{l}\text { 2nd } \\
\text { derivative } 1 \text { st } \\
\text { ROI }\end{array}$ & $\begin{array}{l}\text { Reflectance } \\
\text { 2nd ROI }\end{array}$ & $\begin{array}{l}\text { 2nd derivative } \\
\text { 2nd ROI }\end{array}$ & $\begin{array}{l}\text { Reflectance 1st } \\
\text { ROI }\end{array}$ & $\begin{array}{l}\text { 2nd } \\
\text { derivative 1st } \\
\text { ROI }\end{array}$ & $\begin{array}{l}\text { Reflectance } \\
\text { 2nd ROI }\end{array}$ & $\begin{array}{l}\text { 2nd derivative } \\
\text { 2nd ROI }\end{array}$ \\
\hline Kaolinite & Talc & $10 \%$ & $5 \%$ & $10 \%$ & $5 \%$ & $10 \%$ & $5 \%$ & $10 \%$ & $5 \%$ \\
\hline Kaolinite & Muscovite & $40 \%$ & $20 \%$ & $40 \%$ & $40 \%$ & $50 \%$ & $5 \% / 10 \%$ & $40 \%$ & - \\
\hline Kaolinite & Fe-Mg chlorite & $40 \%$ & $5 \%$ & $40 \%$ & - & $40 \%$ & $5 \%$ & $30 \%$ & $5 \%$ \\
\hline Montmorillonite & Fe-Mg chlorite & $30 \%$ & $10 \%$ & $50 \%$ & - & $20 \%$ & $5 \%$ & $40 \%$ & - \\
\hline Montmorillonite & Clinochlore & $30 \%$ & $5 \%$ & $20 \%$ & $5 \%$ & $30 \%$ & $10 \%$ & $30 \%$ & $10 \%$ \\
\hline
\end{tabular}

a routine library. The absorption bands of an unknown/uncharacterized clay mineral species are impacted by of several parameters (crystal chemistry, the degree of crystallinity, texture, water content, concentration, and matrix composition, as well as other factors), which cannot be addressed through the use of reference spectra chosen by an algorithm.

The main goal of this methodological study was to improve the use of field-based Near-IR spectroscopy for the detailed investigation of the phyllosilicates related to hypogene ore deposits at depth, based on overlying kaolinized saprolite. Saprolite is well known as the worst material in which to identify the distinctive spectral signatures of hypogene phyllosilicates such as muscovite-illite, chlorite or talc. Indeed, they are largely obliterated by the absorption features of kaolinite and/ or smectite that predominate in alteration profiles. However, properly determining the mineralogical composition and the spatial distribution of hypogene alteration products using reflectance spectroscopy in saprolite would significantly reduce the expenditure on exploration for metal deposits located in intertropical countries.

This study showed that it is possible to lower the detection limits of hypogene phyllosilicates to $<10 \%$ of the clay material of the saprolites (Table 2), provided that we use the second derivative methodology. The application of such a methodological procedure can also provide semiquantitative estimation of hypogene phyllosilicates in lateritic clays. These two variables constitute an important prerequisite to the mapping of the alteration zoning of ore deposits at depth that are located under lateritic covers.

Using the NIR spectroscopy, it is important to keep in mind that the accuracy of identification and semi-quantification of phyllosilicates will be substantially improved if the unknown spectra are compared with those of mixtures made of standards phyllosilicates which crystal characteristics are similar to those of the phyllosilicates of the studied exploration area. Indeed as explain earlier, crystal-chemistry of those minerals will influence their second derivative spectra and will probably cause slight changes on the calibration curve. Choosing appropriate mineral references and calibration curves would minimize the influence of unaddressed variables, such as crystal chemistry and the degree of crystallinity, on the position and the profile of the infrared bands of natural or synthetic phyllosilicates (Hunt, 1977; Hauff, 2014; Aung et al., 2015). The impact of those changes must be tested in order to enhance this methodology.

Only binary admixtures of phyllosilicates have been tested to produce the calibration curves. However, new calibration curves must be established if more than two major types of phyllosilicates coexist in the studied natural samples. Note that the semi-quantitative estimation of phyllosilicates ratio obtained from the calibration curves are relevant even if they seem less accurate compared to the results of other longer quantification methodologies.

\section{Acknowledgements}

The authors want to thank the "Société des Mines d'Ity" for the funding support of this study and for the loan of the studied natural samples. 


\section{Appendix}
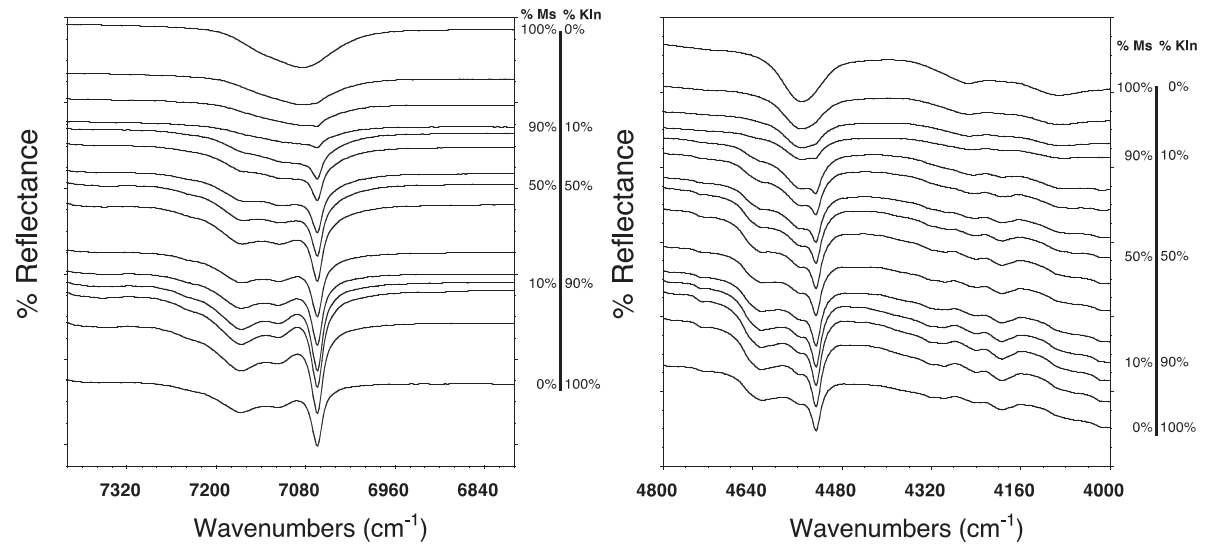

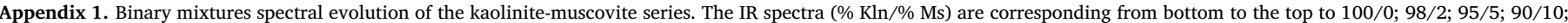
$80 / 20$; 70/30; 60/40; 50/50; 40/60; 30/70; 20/80; 10/90; 5/95; 2/98; 0/100 in the first (A) and second ROI (B).
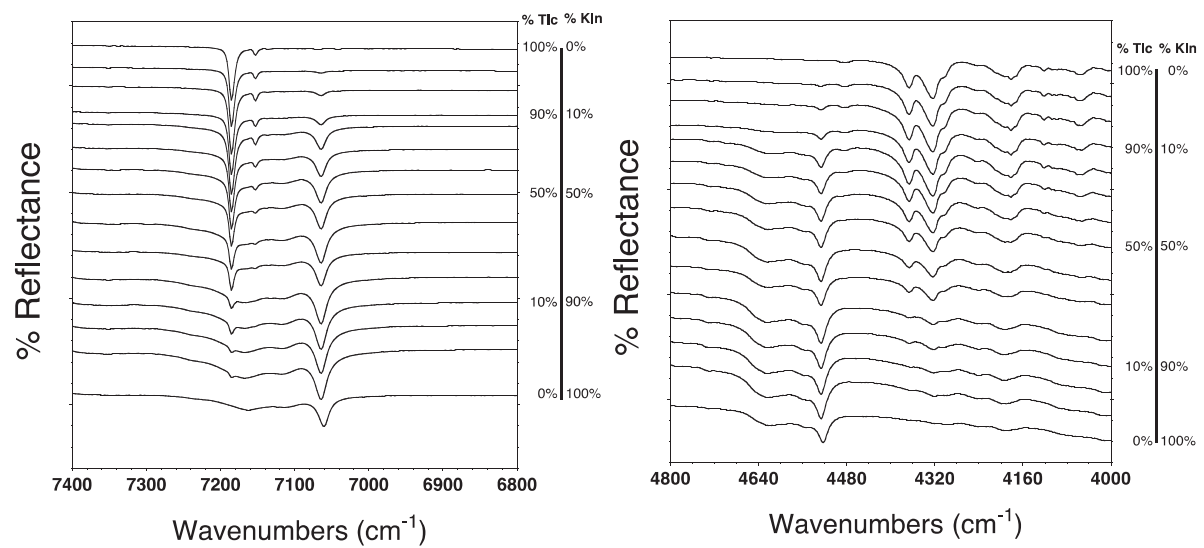

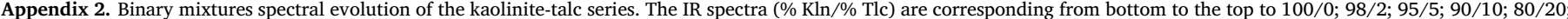
$70 / 30 ; 60 / 40 ; 50 / 50 ; 40 / 60 ; 30 / 70 ; 20 / 80 ; 10 / 90 ; 5 / 95 ; 2 / 98 ; 0 / 100$ in the first (A) and second ROI (B)
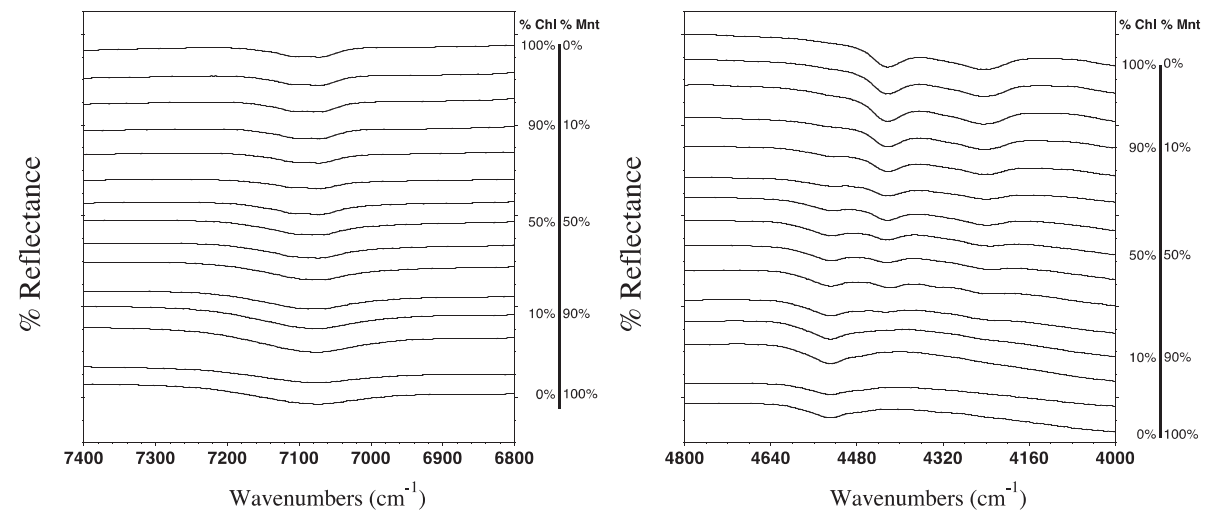

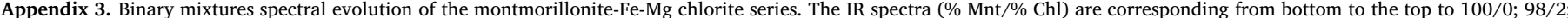
95/5; 90/10; 80/20; 70/30; 60/40; 50/50; 40/60; 30/70; 20/80; 10/90; 5/95; 2/98; 0/100 in the first (A) and second ROI (B) 

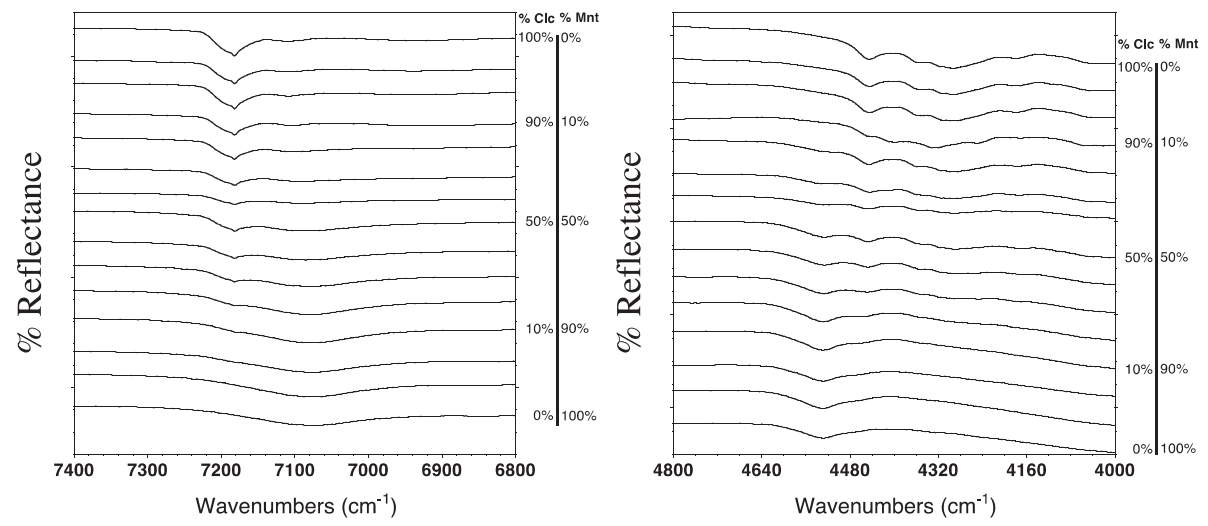

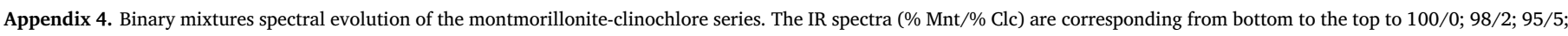
$90 / 10 ; 80 / 20 ; 70 / 30 ; 60 / 40 ; 50 / 50 ; 40 / 60 ; 30 / 70 ; 20 / 80 ; 10 / 90 ; 5 / 95 ; 2 / 98 ; 0 / 100$ in the first (A) and second ROI (B)
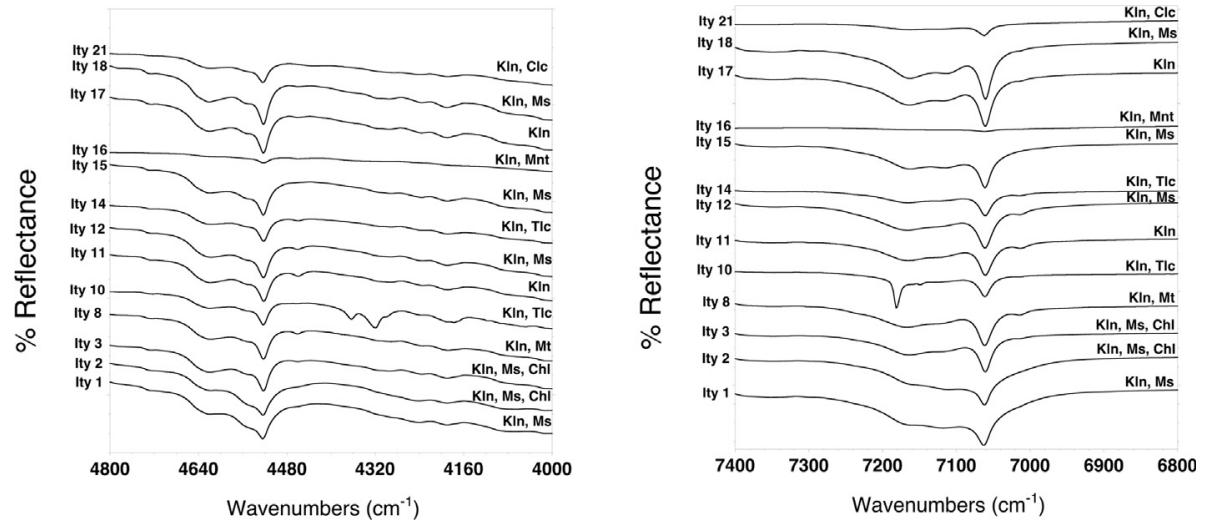

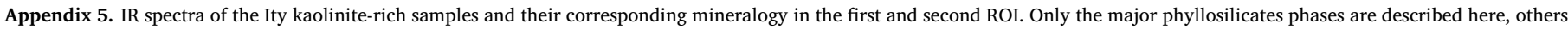
like montmorillonite, talc and chlorite can also be present in the samples but under the detection limit of the IR
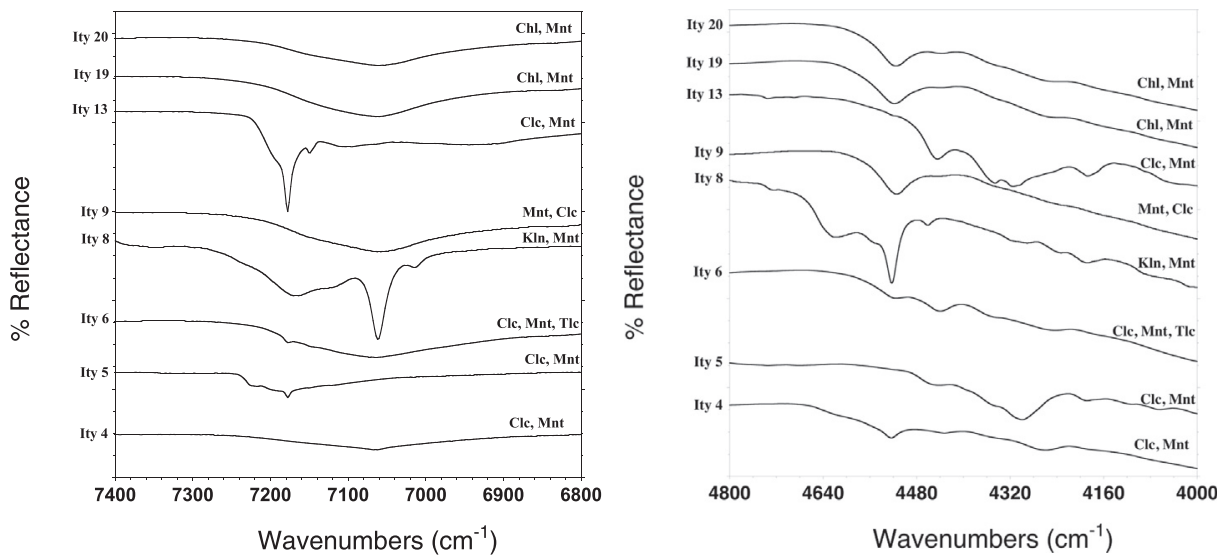

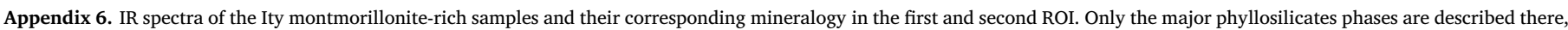
others like talc and kaolinite can also be present in the samples but under the detection limit of the IR

\section{Appendix 7. So how to use the second derivative methodology?}

1- After collecting samples in the field, crush them slightly to obtain a homogeneous powder. Crushing under ethanol prevents any crystallographic disturbance.

2- Dry the sample powders to prevent water disturbance of the IR signal. It can be done using a microwave oven for quicker drying (as described in the Sampling section).

3- Acquire the IR spectra of the sample powders with a field-based spectrometer.

4- From this step, you must be able to recognize the supergene phyllosilicate and/or the hypogene phyllosilicate IR diagnostic bands using the absorption band wavelengths provided in the first part of this work. In case where hypogene IR bands are clearly visible on the spectra, there is no need to use the second derivative methodology. In the other case you will need to apply this very sensitive methodology. 
5- In case you suppose the presence of hypogene or supergene phyllosilicates but you are not seeing them clearly, apply the derivation process on your samples spectra using the software related to the spectrometer. Remember, there is no second derivative option for The Spectral Geologist ${ }^{\mathrm{TM}}$ (TSG) software, you can directly use this option without further steps. If you use the OMNIC ${ }^{\mathrm{TM}}$ software, we advise you to choose "a set of 13 points" parameter and a "polynomial function of order 3" to get the optimal second derivative spectrum resolution.

6- Select the intensity ratios that correspond to the combination of the main hypogene and supergene phyllosilicates of your samples individually (Appendix 8).

7- Measure the intensity values, from the second derivative curve (from $\mathrm{Y}=0$ to your maximal/minimal intensity), at the two specified wavelengths of the intensity ratio that you selected. Calculate the ratio value and use it in the regression curve formula to see if the target phyllosilicate is present or not. You can also obtain the relative percentage of the target phyllosilicate compared to the total mass of phyllosilicate of your sample.

In case where the relative percentage value would be lower than the detection limit established in this work (Table 2), this methodology cannot assess that the target phyllosilicate is present in the sample.

In case where the relative percentage value would be higher than the detection limit, this value can be considered as an imprecise semiquantitative value, in the range defined by the calibration curve.

You can also compare the estimated relative percentage obtained from the first and second ROI (if available).

Appendix 8

Table with the qualitative parameters of each binary admixture and the related detection limits for both ROI

\begin{tabular}{lllll}
\hline Binary admixture & 1st ROI qualitative parameter & Detection limit & 2nd ROI qualitative parameter & Detection limit \\
\hline Kaolinite/muscovite & $\mathrm{I}_{2195} / \mathrm{I}_{2208}$ & $5 \%$ & $\mathrm{I}_{1395} / \mathrm{I}_{1415}$ & $70 \%$ \\
& $\mathrm{I}_{2350} / \mathrm{I}_{2385}$ & $10 \%$ & & \\
Kaolinite/talc & $\mathrm{I}_{2315} / \mathrm{I}_{2208}$ & $5 \%$ & $\mathrm{I}_{1395} / \mathrm{I}_{1415}$ & $5 \%$ \\
Kaolinite/chlorite & $\mathrm{I}_{2250} / \mathrm{I}_{2355}$ & $5 \%$ & $\mathrm{I}_{1415} / \mathrm{I}_{1395}$ & $5 \%$ \\
Smectite/chlorite & $\mathrm{I}_{2255} / \mathrm{I}_{2205}$ & $5 \%$ & $/$ & $/$ \\
Smectite/clinochlore & $\mathrm{I}_{2245} / \mathrm{I}_{2208}$ & $10 \%$ & $\mathrm{I}_{1392} / \mathrm{I}_{1415}$ & $10 \%$ \\
\hline
\end{tabular}

\section{References}

Aung, L.L., Tertre, E., Petit, S., 2015. Effect of the morphology of synthetic kaolinites on their sorption properties. J. Colloid Interface Sci. 443, 177-186.

Baron, F., Petit, S., 2016. Interpretation of the infrared spectra of the lizardite-nepouite series in the near- and mid-infrared range. Am. Mineral. 101, 423-430.

Béziat, D., Siebenaller, L., Salvi, S., Chevalier, P., 2016. A weathered skarn-type mineralization in Ivory Coast: the Ity gold deposit. Ore Geol. Rev. 78, 724-730.

Bishop, J.L., Lane, M.D., Dyar, M.D., Brown, A.J., 2008. Reflectance and emission spectroscopy study of four groups of phyllosilicates: smectites, kaolinite-serpentines, chlorites and micas. Clay Miner. 43, 35-54.

Cerny, P., Blevin, P.L., Cuney, M., London, D., 2005. Granite-related ore deposits. In: Economic Geology, 100th Anniversary Volume, pp. 337-370.

Dalm, M., Buxton, M.W.N., Van Ruitenbeek, F.J.A., Voncken, J.H.L., 2017. Application of near-infrared spectroscopy to sensor based sorting of a porphyry copper ore. Miner. Eng. 58, 7-16.

Dill, H.G., 2016. Kaolin: Soil, rock and ore from the mineral to the magmatic, sedimentary and metamorphic environment. Earth-Sci. Rev. 161, 16-129.

Edwards, R.P., Atkinsons, K., 1986. Ore Deposit Geology and Its Influence on Mineral Exploration. Springer, Netherland.

Einaudi, M.T., 1982. General features and origin of skarns associated with porphyry copper. In: Advances in Geology of the Porphyry Copper Deposits Southwestern North America. The University of Arizona Press, Tucson (Arizona), pp. 185-210.

Ferrage, E., Martin, F., Micoud, P., Petit, S., Parseval, P., Beziat, D., Ferret, J., 2003. Cation site distribution in clinochlores a NIR approach. Clay Miner. 38, 329-338.

Feybesse, J.L., Milési, J.P., 1994. The Archean/Proterozoic contact zone in West Africa: a mountain belt of décollement thrusting and folding on a continental margin related to 2.1 Ga convergence of Archaean craton? Precambrian Res. 69, 199-227.

Hauff, P., 2014. An Overview of VIS-NIR-SWIR Field Spectroscopy as Applied to Precious Metals Exploration. Spectral International Inc.

Herrmann, W., Blake, M., Doyle, M., Huston, D., Kamprad, J., Merry, N., Pontual, S., 2001. Short wavelenght infrared (SWIR) spectral analysis of hydrothermal alteration zones associated with base metal sulphide deposits at Roseberv and Western Tharsis, Tasmania, and Highway Reward, Queensland. Econ. Geol. 96 (5), 939-955.

Hirdes, W., Davis, D.W., Lüdtke, G., Konan, G., 1996. Two generation of Birimian (Paleoproterozoic) volcanic belts in northeastern Côte d'Ivoire (West Africa): consequences for the Birimian controversy. Precambrian Res. 80, 173-191.

Hunt, G.R., 1977. Spectral signatures of particulate minerals in the visible and near infrared. Geophysics 42, 501-513.

Hunt, G.R., Ashley, R.P., 1979. Spectra of altered rocks in the visible and near infrared. Econ. Geol. 74 (7), 1613-1629.
Joussein, E., Petit, S., Decarreau, A., 2001. Une nouvelle méthode de dosage des minéraux argileux en mélange par spectroscopie IR. C. R. Acad. Sci. Ser. IIA, Earth Planet. Sci. 332, 83-89.

Lawrence, D.M., Treolar, P.J., Rankin, A.H., Harbidge, P., Holliday, J., 2013a. The geology and mineralogy of the Loulo mining district, Mali, West Africa: evidence for two distinct styles of orogenic gold mineralization. Econ. Geol. 108, 199-227.

Lawrence, D.M., Treolar, P.J., Rankin, A.H., Boyce, A., Harbidge, P., 2013b. A fluid inclusion and stable isotopes study at the Loulo mining district, Mali, West Africa: implication for multifluid sources in the generation of orogenic gold deposits. Econ. Geol. 108, 229-257.

Leube, A., Hirdes, W., Mauer, R., Kesse, G.O., 1990. The early Proterozoic Birimian supergroup of Ghana and some aspects of its associated gold mineralization. Precambrian Res. 46, 139-165.

Lisowiec, N., Halley, S., H., Ryan, L., 2007. Using deposit-scale alteration and geochemical signatures to explore for analogue deposits: a case study from the Mt Wright Gold Project, Queensland. In: Geochemical Case Histories and Geochemical Exploration Methods, pp. 969-972.

Madejova, J., Balan, E., Petit, S., 2011. Application of vibrational spectroscopy to the characterization of pyllosilicates and other industrial minerals. In: EMU Notes in Mineralogy. vol. 9. European Mineralogical Union, pp. 171-226.

Mathian, M., Beaufort, D., Lescuyer, J.L., Furic, R., 2015. Application de la spectroscopie infrarouge portable à l'identification des phyllosilicates des roches sous couverture latéritique: Cas d'étude du prospect minier du Mont Ity (Côte d'Ivoire) (Master thesis). .

Meinert, L., Dipple, G.M., Nicolescu, S., 2005. World skarn deposits. In: Economic Geology, 100th Anniversary Volume, pp. 299-336.

Milesi, J.P., Feybesse, J.L., Ledru, P., Domanget, A., Ouedraogo, M.F., Marcoux, É., Prost, A., Vinchon, C., Sylvain, J.P., Johan, V., Tegyey, M., Calvez, J.Y., Lagny, P., 1989. Les minéralisations aurifères de l'Afrique de l'Ouest. Chron. Rech. Min. 497, 3-98.

Petit, S., Madejova, J., Decarreau, A., Martin, F., 1999. Characterization of octahedral substitutions in kaolinites using near infrared spectroscopy. Clay Clay Miner. 47, 103-108.

Petit, S., Decarreau, A., Martin, F., Buchet, R., 2004a. Refined relationship between the position of the fundamental $\mathrm{OH}$ stretching and the first overtones for clays. Phys. Chem. Miner. 31, 585-592.

Petit, S., Martin, F., Wiewiora, A., De Parseval, P., Decarreau, A., 2004b. Crystal-chemistry of talc: a near infrared (NIR) spectroscopy study. Am. Mineral. 89, 319-326.

Pontual, S., Merry, N., Gamson, P., 1997. Spectral Interpretation Field Manual GMEX. Ausspec International Pty.

Post, J.L., Crawford, S.M., 2014. Use of near-infrared spectra for the identification of clay minerals. Appl. Clay Sci. 95, 383-387.

Post, J.L., Noble, P.N., 1993. The near-infrared combination band frequencies of 
dioctahedral smectites, micas and illites. Clay Clay Miner. 41 (6), 639-644. Quirt, D.H., 1995. Norm calculation procedure for sandstone clay minerals. In: Saskatchewan Research Council, Publication No. R-1230-28-E-95, pp. 14.

Ramanaidou, E.R., Wells, M., 2015. A new toolkit for iron ore characterisation. Proc. Iron Ore 2015, 587-590.

Seedorff, E., Dilles, J.H., Proffett Jr., J.M., Einaudi, M.T., Zurcher, L., Stavast, W.J.A., Johnson, D.A., Barton, M.D., 2005. Porphyry deposits: characteristics and origin of hypogene features. In: Economic Geology, 100th Anniversary Volume, pp. 251-298. Simmons, S.F., White, N.C., John, D., 2005. Geological characteristics of epithermal precious and base metal deposits. In: Economic Geology, 100th Anniversary Volume, pp. $485-522$.

Sun, Y., Seccombe, P.K., Yang, K., 2001. Application of short-wave infrared spectroscopy to define alteration zones associated with the Elura zinc-lead-silver deposit, NSW, Australia. J. Geochem. Explor. 73, 11-26.

Thompson, A.J.B., Hauff, P.L., Robitaille, A.J., 1999. Alteration mapping in exploration: application of short-wave infrared (SWIR) spectroscopy. Soc. Econ. Geol., Newsl. 39, 16-27.

Vaculikova, L., Plevova, E., 2005. Identification of clay minerals and micas in sedimentary rocks. Acta Geodyn. Geomater. 2 (138), 167-175. 